\title{
LA CRÍTICA DE BRUNO EN EL CANDELAIO Y LOS DIALOGHI ITALIANI
}

\author{
Montserrat Bartolomé Luises \\ (IES Antonio Machado - Soria)
}

El proceso secular y relativo de la vicisitud de las cosas explica el desarrollo histórico de la humanidad. En la vicisitud infinita de la rueda del tiempo, el sentido y el significado de la vida se hallan unidos al desvelamiento de la antigua sabiduría, a la restauración de la antigua verdad. Bruno considera que su destino es divino, ligado a la verdad eterna que se manifiesta en la historia cíclica de la humanidad. Se trata de encontrar una ley universal al amparo de un nexo constitutivo entre razón y justicia, que restituya no sólo el orden y el sentido del universo sino también de lo diferente, particular e individual. La escisión entre ley y verdad y la pérdida de autoridad de la filosofía revelan la crisis de su tiempo histórico, que se halla en el punto más bajo de la rueda de la civilización, de suerte que su vejez debe dar paso a la juventud y renovación que propone la nueva filosofía de Bruno ${ }^{1}$. Su visión crítica de Europa se ampara en una

\footnotetext{
${ }^{1}$ G. Bruno, De immenso et innumerabilibus, en Jordani Bruni Nolani, Opera latine conscripta, publicis sumptibus edita, recensebat F. Fiorentino [F. Tocco, H. Vitelli, V. Imbriani, C.M. Tallarigo], Neapoli, apud Domenico Morano [Florentiae, typis successorum Le Monnier], MDCCCLXXIX-XCI, 3 vols. en 8 partes (reimpresión en facsímil, Friedrich Fromman Verlag Gunther Holzboog, Stuttgart - bad Cannstatt, 1962), I, 1 (liber I-III), I, 2 (liber IV-VIII), liber I, p. 208 y liber VIII, pp. 317-318; De l'infinito universo e mondi, en Dialoghi italiani. I. Dialoghi metafisici. II. Dialoghi morali, nuovamente ristampati con note di Giovanni Gentile, terza edizione a cura di Giovanni Aquilecchia, Firenze, Sansoni, 1958 (seconda ristampa, 1985), p. 346; La Cena de le ceneri, en Dialoghi italiani. I. Dialoghi metafisici. II. Dialoghi morali, cit., p. 76; Spaccio de la bestia trionfante, en Dialoghi italiani. I. Dialoghi metafisici. II. Dialoghi morali, cit., pp. 550-551 y 786. Según G. Gentile (Giordano Bruno e il pensiero del rinascimento, con una Introduzione di E. Garin, Firenze, 1991, pp. 3, 36-38 y 110), el hombre es, por la libertad y el trabajo, el protagonista y creador de su mundo, civilización y destino en la historia y, en este sentido, Bruno es la conclusión lógica de todo lo que representa el Renacimiento frente a la Edad Media.
}

Philosophica, 33, Lisboa, 2008, pp. 119-158 
original concepción no sólo del universo, la naturaleza y el hombre, sino también de la lengua, la política y la religión. La nueva filosofía tiene que iluminar la noche de la ignorancia para rescatar el destino individual de los hombres y contemplar la eterna verdad en el fondo de las cosas.

El Candelaio, los Dialoghi italiani y los tres poemas latinos representan la culminación de la filosofía de Bruno. En ellos desarrolla su ontología de la materia eterna, su cosmología del universo infinito e innumerables mundos, su reforma ética, política y religiosa, y su idea del furor heroico como la forma más elevada de la verdad y la felicidad. Se puede decir que la andadura filosófica de Bruno se inicia en Londres, en el año 1584, con el diálogo La Cena de le Ceneri, al que le siguen el De la causa, principio e uno, el De l'infinito, universo e mondi y el Spaccio de la bestia trionfante; en 1585, se editan la Cabala del Cavallo Pegaseo con l'aggiunta dell'Asino Cillenico y el De gli eroici furori². Tanto en el De la causa cuanto en el De l'infinito se tratan los conceptos de máximo absoluto y máximo contracto que se verifican en el Spaccio desde la óptica de la vida civil y religiosa y en los Eroici desde el punto de vista cognoscitivo. En 1591, se publican en Frankfurt el De innumerabilibus immenso et infigurabili; seu de universo et mundis libri octo; el De monade, numero et figura, secretioris nempe physicae, mathematicae et metaphysicae elementa y el De triplici minimo et mensura ad trium speculativarum scientiarum et multarum activarum artium principia libri $V^{3}$. En La Cena, el De la causa y el De l'infinito, defiende su concepción heliocéntrica del universo, y mantiene discusiones metafísicas sobre la naturaleza con la Física de Aristóteles. El De immenso lo empezó a escribir en Londres, en $1584^{4}$, y presenta una

2 Cfr. G. Aquilecchia, Giordano Bruno, Roma, 1971, p. 50; G. Gentile, ed. Dialoghi italiani. I. Dialoghi metafisici. II. Dialoghi morali, cit., pp. XXX-XXXIII y LXI. Respecto de los diálogos metafísicos, cfr. A. Guzzo, ed. De la causa, principio e uno, Milano, 1985, p. 19. Entre 1583 y 1585 acontece la experiencia inglesa de Bruno, cuyo fruto esencial son sus diálogos italianos. Bruno escribe en italiano los diálogos londinenses no sólo porque entre los que formaban parte de la corte de la reina Isabel había personas con inclinación hacia la cultura italiana, por ejemplo, Sir Philip Sydney (poeta "petrarquista"), al que Bruno dedicó el Spaccio y los Furori, sino también por el sentido práctico y unitario - relacionado con la política marítima de expansión- que las grandes naciones europeas querían dar a la educación científica, matemática y astronómica. La moda cortesana se manifiesta, en los diálogos, de un modo fragmentario y modesto (ni siquiera predomina en el lenguaje y estilo de las epístolas dedicatorias), y la exigencia científico-didáctica se revela en los diagramas geométricos. Sobre la adopción de la lengua vulgar en los diálogos londinenses de Bruno, cfr. G. Aquilecchia, I dialoghi italiani (varietà di variante), en AA.VV., Giordano Bruno. Note filologiche e storiografiche, Firenze, 1996, pp. 26-27.

3 Cfr. F. Fiorentino, Opera latine conscripta, publicis sumptibus edita, recensebat F. Fiorentino, Neapoli, apud Domenico Morano, MDCCCLXXIX, vol. I, pars 1, p. XXVII.

${ }^{4}$ En Londres se gesta e inicia el De immenso, ya que en 1585 Bruno regresa a París con la misma y escasa ropa de siempre y con los tres primeros libros del De immenso. En este sentido, cfr. F. Fiorentino, op. cit., pp. XXVII-XXXII. 
especie de compendio de toda su filosofía; el De monade y el De minimo, escritos posteriormente, ofrecen un cuerpo de teorías que fundamentan su teoría del universo expuesta en el De inmenso. Éste se asemeja, por su contenido, a los tres primeros diálogos italianos ${ }^{5}$, y es considerada su principal obra ${ }^{6}$, ya que elabora y corrige La Cena y el De l'infinito, añadiendo conceptos y demostraciones de carácter físico y científico; refuta la física de Aristóteles y, bajo la teoría copernicana, propone una nueva intuición del universo, en cuyo etéreo e inmenso espacio acontece la fusión y comunicación de la divina naturaleza con la infinita potencia viviente, que es la causa y el origen de todas las cosas.

En el Candelaio y los Dialoghi italiani, la restauración universal de la filosofía y la ciencia se relaciona con la dimensión ética y lingüística de los hombres. Bruno denuncia la búsqueda de la gloria vulgar que procede del pueblo y de los poderosos, y la limitación de los hombres incapaces de alcanzar la sabiduría por estar doblegados a la autoridad de la filosofía aristotélica y a la de la religión. Frente a la luz de la verdad filosófica, la insensatez habita en las tinieblas y en la ignorancia cristiana. Las sombras o creencias del vulgo se oponen al furor lírico y contemplativo. Mensajero de la luz en el De umbris y Candelaio, héroe solar en La Cena, y especialista en curar los males de la humanidad en el De la causa, Bruno se considera el Mercurio de una nueva filosofía que liberará al hombre de la decadencia de su mundo. Sus Sombras de las ideas permiten alejarse de las bestias, los asnos y los diablos dantescos ${ }^{7}$, de los maestros de medicina, filosofía y teología, que presumen de interpretar con exactitud los tradicionales y difíciles autores ${ }^{8}$, de sus adversarios en lecciones universitarias, de los que en el Cantus son transformados por la maga Circe en el mono, por mezclar lo serio con lo ridículo, en el mulo, por presumir de orador y filósofo sin serlo, en el pavo, por actuar para ser alabado, en el ruiseñor, porque su saber es vulgar y no culto 9 . La sátira bruniana a los pedantes es una reivindicación a la autonomía del pensamiento, tan temida por la irracionalidad de los que maquinaron y calumniaron sus teorías ${ }^{10}$.

${ }^{5}$ Cfr. F. Fiorentino, op. cit., pp. XXVII-XXVIII. Acerca de los tres poemas latinos, véase la excelente introducción de C. Monti, ed. Il triplici minimo e la misura. La monade, il numero e la figura. L'immenso e gli innumerevoli, Torino, 1980, pp. 9-62.

${ }^{6}$ Cfr. F. Fiorentino, op. cit., pp. XXV-XXVI.

7 Cfr. G. Bruno, Candelaio, ed. G. Bárberi Squarotti, Torino, 2000, p. 22.

8 Cfr. G. Bruno, De umbris idearum, en Jordani Bruni Nolani, Opera latine conscripta, cit., II, 1, pp. 11 y 14.

${ }^{9}$ Cfr. G. Bruno, Cantus Circaeus, en Jordani Bruni Nolani, Opera latine conscripta, cit., II, 1, pp. 198-199 у 206.

10 Cfr. G. Bruno, De compendiosa architectura, et complemento artis Lullii, en Jordani Bruni Nolani, Opera latine conscripta, cit., II, 2, p. 5. 


\section{El Candelaio}

El Candelaio se publica en 1582 en París entre dos libros de mnemotecnia (el De umbris y el Cantus) y el De compendiosa architectura, et complemento artis Lullii o al mismo tiempo que éste. Es una tragicomedia ambigua y contradictoria que promete la risa para terminar en el llanto.

Llegaron muchos, unos para reírse, otros para entristecerse, unos llorando, otros riendo, éstos aconsejando, aquéllos esperando, unos poniendo una cara, otros otra, unos usaban un lenguaje y otros otro: se encontraban juntas comedia y tragedia, y los había que tocaban a gloria y quienes tocaban a muerto. De suerte que, quien hubiese deseado ver cómo estaba hecho el mundo, tendría que haber anhelado estar presente ${ }^{11}$.

La risa y el llanto no son dos realidades separadas sino un espacio en el que convergen y se generan elementos contrarios. In tristia hilaris, in hilaritate tristis ${ }^{12}$, expresa la ley general de la coincidentia oppositorum y rompe la rígida oposición entre la risa y el llanto. El pesimismo absoluto

11 G. Bruno, Candelaio, cit., p. 82: "Concorsero molti, de quali altri pigliandosi spasso altri attristandosi, altri piangendo altri ridendo, questi consigliando quelli sperando, altri facendo un viso altri un altro, altri questo linguaggio ed altri quello: era veder insieme comedia e tragedia, e chi sonava a gloria e chi a mortoro. Di sorte che, chi volesse vedere come sta fatto il mondo, derebbe desiderare d'esservi stato presente". Cfr. trad. T. Losada, ed. Candelero, Castellón, 2004, pp. 226-227. Las traducciones del italiano y al español que aparecen en este artículo, he decidido realizarlas personalmente de las ediciones de los Dialoghi italiani y de la Opera latine conscripta, aunque teniendo presente las traducciones del italiano al español de I. Gómez de Liaño, ed. Expulsión de la bestia triunfante y De los heroicos furores, Madrid, 1987; M. Á. Granada, ed. Cábala del Caballo Pegaso, Madrid, 1990; T. Losada, op. cit. Por otra parte, es de gran interés la edición crítica de G. Aquilecchia (Opere italiane) y de R. Sturlese (Opere latine) de algunas obras latinas de Bruno, en Les oeuvres complètes, París, 1993, aunque no interfiere en los textos en italiano que aparecen a lo largo de estas páginas.

12 Cfr. G. Bruno, Candelaio, cit., p. 17; De vinculis in genere, en Jordani Bruni Nolani, Opera latine conscripta, cit., III, p. 690. La vigilia es propia del loco triste, porque el loco bueno está muerto y el indiferente se halla dormido (cfr. G. Bruno, Candelaio, cit., p. 161). Cfr. op. cit., p. 64: "I savi vivono per i pazzi, ed i pazzi per i savii. Si tutti fussero signori, non sarebbono signori: cossí, se tutti saggi, non sarebbono saggi, e se tutti pazzi, non sarebbono pazzi. Il mondo sta bene come sta". ["Los sabios viven gracias a los locos, y los locos gracias a los sabios. Si todos fueran señores, no habría señores; si todos fueran sabios, no habría sabios; si todos fueran locos, no habría locos. El mundo está bien como está"]. Cfr. trad. T. Losada, op. cit., pp. 197-198. En la mitología griega, Momo (cfr. G. Bruno, op. cit., p. 149) era el dios de la risa y de la burla, y personificaba la sátira y la broma. 
de Heráclito se opone a la actitud optimista de Demócrito ${ }^{13}$, pero hay una contigüidad entre Demócrito que se reía de todas las preocupaciones humanas y Heráclito que lloraba porque veía el fluir y el pasar de todo. La tristeza representa el pasado y la decadencia. La hilaridad simboliza el futuro, el nuevo proyecto del hombre y del universo. Lo real es inestable, contradictorio y en continuo movimiento, y revela un mundo alejado del equilibrio en que tragedia y comedia, risa y llanto, interactúan sin cesar entre sí.

Ambientes, personajes y sentimientos coinciden con los vividos por Bruno. De hecho, el Candelaio es una comedia de carácter napolitano por su ambientación, personajes y lenguaje; alusiones y recuerdos se vinculan a la historia, leyes, hábitos, proverbios y expresiones populares de Nápo${ }_{1} \mathrm{~s}^{14}$. Es muy elocuente la imagen que al inicio presenta de sí mismo:

Si conocierais al autor, diríais que tiene un aire perdido, parece contemplar siempre las penas del infierno, haber estado metido en la prensa como el fieltro, uno que ríe únicamente para hacer lo mismo que los demás; la mayor parte de las veces lo veréis fastidiado, terco y extravagante: no se contenta con nada, recalcitrante como un viejo de ochenta años, antojadizo como un perro desollado, llorón como un comedor de cebolla. Por la sangre de... no quiero decir que él y todos los demás filósofos, poetas y pedantes no tengan mayor enemigo que la riqueza y los bienes: mientras que los diseccionan con el intelecto, huyen de éstos como del diablo para no ser desgarrados, descuartizados y derrochados y van al encuentro de quienes los mantienen sanos y en reserva. Así es que yo, al servir a semejante canalla, tengo tanta hambre, tanta hambre que si tuviese necesidad de vomitar, no podría vomitar nada más que mi último suspiro; si por fuerza tuviese que cagar, sólo podría cagar el alma como un ahorcado. Conclusión: voy a hacerme monje, y que represente el prólogo quien quiera ${ }^{15}$.

13 Cfr. G. Bruno, op. cit., p. 32. La armonía de los contrarios de Heráclito y el naturalismo de Demócrito son dos influencias fundamentales en la filosofía de Bruno.

14 Cfr. G. Bruno, op. cit., p. 31.

15 G. Bruno, Ibidem: 'L'autore, si voi lo conosceste, dirreste ch'ave una fisonomia smarrita: par che sempre sii in contemplazione delle pene dell'inferno, par sii stato alla pressa come le barrette: un che ride sol per far comme fan gli altri: per il piú, lo vedrete fastidito, restio e bizzarro, non si contenta di nulla, ritroso come un vecchio d'ottant'anni, fantastico com'un cane ch'ha ricevute mille spellicciate, pasciuto di cipolla. Al sangue, non voglio dir de chi, lui e tuti quest'altri filosofi, poeti e pedanti la piú gran nemica che abbino è la ricchezza e beni: de quali mentre col lor cervello fanno notomia, per tema di non essere da costoro da dovero sbranate, squartate e dissipate, le fuggono come centomila diavoli, e vanno a ritrovar quelli che le mantengono sane ed in conserva. Tanto che io, con servir simil canaglia, ho tanta de la fame, tanta de la fame, che si me bisognasse vomire, no potrei vomir 
En el Candelaio presenta una imagen feroz y desencantada de la vida y del mundo bajo el caótico espacio urbano de Nápoles, en el que se mezclan imágenes desordenadas que devienen en un fantástico caos cósmico ${ }^{16}$. El teatro del mundo, imagen primordial del caos, se expresa y se entiende en el teatro de la mente, en la conciencia de la enajenación del hombre, mediante imágenes y palabras del espacio caótico cósmico. En el teatro de la conciencia se expresa la decadencia del hombre y se articula con el teatro del mundo, con el espacio socio-cultural, que representa la crisis de Europa. Nápoles es la negación de la civilización, de su vida social, política, económica y cultural. El comercio con lo sagrado, con las supersticiones y reliquias se revela en las formas anónimas de prostitución, zonas de trabajo, maleantes, circulación de monedas, religiosidad, tradiciones. Se trata de una comedia que representa la tragedia de un mundo decadente, sórdido, torpe y delirante, en el que se ha invertido la pasión amorosa, el anhelo de investigación científica y el uso del lenguaje. Los protagonistas se presentan al amparo de las máscaras petrarquista, alquimista y pedante. Estas manifestaciones decadentes del mundo utilizan o bien el lenguaje cómico e irracional de la poesía de Petrarca y de sus seguidores, o bien el lenguaje pseudonatural de la alquimia, o bien el latín del humanismo y la escolástica. Bonifacio es "el insípido amante", el símbolo del amor de Petrarca. El alquimista Bartolomeo es "el sórdido avaro". El torpe Manfurio es "el golfo pedante", el emblema de la pedantería gramatical y lingüística. Manfurio representa a los que huyen de la libre imaginación filosófica y se rinden a la autoridad de la física y retóri-

altro ch'il spirto; si me fusse forza di cacare, non potrei cacar altro che l'anima, com'un appiccato. In conclusione, io voglio andar a farmi frate; e chi vuol far il prologo, sel faccia". Cfr. trad. T. Losada, op. cit., pp. 135-136.

16 Para Bruno (op. cit., p. 22), el caos es una de las condiciones fundamentales en la escala del ser. El límite del caos articula y media entre la vida cotidiana de Nápoles, donde reside la Signora Morgana, a quien dedica el Candelaio, y París, donde vive Bruno. El espacio urbano de Nápoles es el espejo del caos, el receptáculo mental de imágenes que proceden del ilimitado lugar cósmico representado por París, en que la fantasía crea infinitas formas mezcladas y confundidas de todos los cuerpos, con el fin de que la memoria las retenga. Nápoles es un espacio real, mental y viviente, cuyas imágenes reflejan el ocaso napolitano, italiano y europeo. En este sentido, cfr. P. Sabbatino, Giordano Bruno e la "mutazione" del Rinascimento, Firenze, 1993, ristampa 1998, pp. 8, 51-52, 54, 56-57, 66-67 y 80-81. En el Lampas triginta statuarum (en Jordani Bruni Nolani, Opera latine conscripta, cit., III, pp. 9-10, 12-14 y 93), el abismo es la imagen del caos, que es el principio de todas las formas confundidas y mezcladas, y en el que la multiplicación de formas es impulsada hacia el infinito, en un engranaje combinatorio de unión y separación, composición y descomposición, originando una metamorfosis permanente. El caos es un gran vacío ajeno a todo cuerpo y materia y con la capacidad de abarcar todas las figuras, cuerpos y materias, sin alcanzar nunca la plenitud. En la unidad de este espacio vacío, receptáculo invisible, acaece la diferencia y división de los cuerpos. 
ca aristotélica por su incapacidad para pensar por sí mismos. Mediante el amor de Bonifacio, la alquimia de Bartolomeo y la pedantería de Manfurio ${ }^{17}$, Bruno expone la corrupción de las costumbres y las vilezas de sus personajes, las tristes consecuencias del poder español, y la decadencia del saber y de la superstición. En virtud de ello aparecerán:

(...) teorías ociosas, planes flojos, pensamientos vanos, frívolas esperanzas, explosiones de amor, revelaciones del corazón, suposiciones falsas, alienaciones de la mente, furores poéticos, ofuscamiento de los sentidos, turbación de la fantasía, peregrinación perdida del entendimiento, creencias desenfrenadas, curas insensatas, estudios inciertos, semillas improcedentes y gloriosos frutos de locura ${ }^{18}$.

En el Candelaio, la astucia se vincula a la invención lingüística, que expresa el amor ridículo de Bonifacio hacia Victoria, aproximándose a ella travestido del pintor Giovan Bernardo, el uso de la ropa de Victoria por parte de Carubina para sorprender a su marido Bonifacio y vengarse de su engaño, la actitud persuasiva de Bernardo hacia Carubina para que soslaye cualquier escrúpulo moral, la seducción de Cencio a Bartolomeo, convenciéndolo de su capacidad para transformar los metales viles en oro, y las aventuras del pedante Manfurio, burlado y timado por las calles de la ciudad. La obra concluye con el encuentro de todos los personajes, sometidos a las amenazas de un grupo de farsantes. Los personajes de

17 Cfr. G. Bruno, Candelaio, cit., p. 23. Para F. Puglisi (La rivoluzione artistico-filosofica di Giordano Bruno, Roma, 1989, p. 20), tres elementos constituyen la comedia bruniana: la pedantería, la estupidez y la bribonería.

18 G. Bruno, op. cit., p. 38: “(...) ociosi principii, debili orditure, vani pensieri, frivoli speranze, scoppiamenti di petto, scoverture di corde, falsi presupposti, alienazion di mente, poetici furori, offuscamento di sensi, turbazion di fantasia, smarrito peregrinaggio d'intelletto, fede sfrenate, cure insensate, studi incerti, somenze intempestive e gloriosi frutti di pazzia". Cfr. trad. T. Losada, op. cit., p. 138. En el Renacimiento subyace un carácter crítico del valor del propio renacer. De esta crisis y decadencia hablan Maquiavelo, Bruno, Leonardo Bruni, Campanella. La crisis del patrimonio cultural del Renacimiento, anquilosado en los aspectos de su modelo gramatical, petrarquista y pseudo-científico, se inicia en los años ochenta, siendo Bruno uno de los primeros pensadores capaz de afrontarlo, desde una óptica tragicómica, en su obra el Candelaio de 1582, en la que ya se define (op. cit., p.22) como hombre de la mutazione, que representa la clave de su filosofía de la naturaleza. En este sentido, cfr. M. Ciliberto, Umbra profunda. Studi su Giordano Bruno, Roma, 1999, pp. 30-31; P. Sabbatino, op. cit., p. 7. E. Battisti (L'antirinascimento, Milano, 1962) y H. Haydn [Il controrinascimento, Bologna, 1967 (ed. or. New York, 1950)] afirman la existencia de un movimiento crítico de pensadores como Maquiavelo, Agrippa, Montaigne, Lutero, Calvino y Bruno, contra el Renacimiento clásico y su actitud intelectual, moral y autoritaria en la teología, ciencia y literatura. Se trata de una protesta que discute los ideales de equilibrio del humanismo y que disuelve la ciencia aristotélica y el concepto de ley natural universal, para dar paso al empirismo, relativismo y pragmatismo. 
clase social ínfima se burlan de los que pertenecen a la aristocracia "intelectual" y se convierten en los auténticos protagonistas de la comedia. Todos ellos reflejan la situación moral de la época por su amor al dinero fácil, a la prostitución, al lenguaje vacuo, al placer sexual,... En la sociedad de Bruno, la inestabilidad política y la ausencia de valores ha generado una constante tensión en la vida ciudadana y un bandidaje sin control.

La fuerza de los elementos del lenguaje fundamenta la polémica con la cultura y moral de la época. Las formas lingüísticas simbolizan la controversia conceptual y la meditación crítica y subyacen en las situaciones culturales y sociales para garantizar el comportamiento grotesco de los personajes. Bruno se opone a la cultura gramatical, lírica y científica de su época, y utiliza el italiano, una lengua vulgar, contra la literatura, la filosofía y la ciencia tradicionales, cuyo lenguaje carece de contenido. E1 lenguaje amoroso es desmitificado por la experiencia de Bonifacio, el científico por la alquimia de Cencio y Bartolomeo, el latín culto por el pedante Manfurio. En la filosofía de la naturaleza, el lenguaje científico carece de capacidad cognoscitiva; en el ámbito afectivo, el lenguaje lírico y tradicional es vano y absurdo; en la especulación filosófica, el formalismo y la exactitud gramatical son inútiles para la solución de los grandes problemas metafísicos. Las condiciones reales de los sentimientos son ajenas a las habituales deformaciones verbales y a las destructivas y ridículas imágenes amorosas ${ }^{19}$. Las oposiciones conceptuales y las imágenes acentúan la terminología decorativa y mecánica de Bonifacio, que se halla más allá del verdadero mundo afectivo. La filosofía aristotélica y medieval de la naturaleza se sostiene en grotescas nociones sobre el vacío $\mathrm{y}$ en arduas concepciones de principios, metales y fuerzas naturales ${ }^{20}$. El lenguaje pedante ${ }^{21}$, ajeno a la lengua popular, suscita una serie de equívocos verbales y de términos deformados que representan la comunicación

19 Cfr. G. Bruno, op. cit., pp. 32-34.

${ }^{20}$ Cfr. G. Bruno, op. cit., pp. 51-54 y 71-72. De acuerdo con la física aristotélica, cfr. G. Bruno, op. cit., p. 159: non dar vacuo in natura.

21 Cfr. G. Bruno, op. cit., pp. 42-45, 57-62, 87-91, 106-107, 112-115 y 162-165. Sobre la crítica a los pedantes, cfr. G. Bruno, op. cit., pp. 19 y 34-35. Las críticas a la pedantería de los gramáticos son abundantes no sólo en el Candelaio y en los diálogos italianos sino también en las obras latinas; cfr., por ejemplo, G. Bruno, Artificium perorandi traditum a Iordano Bruno, en Jordani Bruni Nolani, Opera latine conscripta, cit., II, 3, p. 376; Camoeracensis acrotismus, en Jordani Bruni Nolani, Opera latine conscripta, cit., I, 1, p. 86; De triplici minimo et mensura, en Jordani Bruni Nolani, Opera latine conscripta, cit., I, 3, liber III, p. 236. La filosofía no se debe regir por la gramática, que es culpable de todos los males de las bellas artes y de la reflexión filosófica; cfr., por ejemplo, De imaginum compositione, en Jordani Bruni Nolani, Opera latine conscripta, cit., II, 3, pp. 92-93; De progressu et lampade venatoria logicorum, en Jordani Bruni Nolani, Opera latine conscripta, cit., II, 3, p. 5. 
docto-escolástica y que reducen la filosofía a mera gramática, privándola de su carácter universal procedente de la admiración ${ }^{22}$. El pedante deforma el lenguaje, mezcla niveles lingüísticos en momentos inadecuados y con un léxico equívoco. Son palabras que no sirven para nada ${ }^{23}$ y que pretenden esconderse de la verdad ${ }^{24}$. Los pedantes son muertos vivientes porque sus palabras son falsas y su doctrina es inútil. El lenguaje obsceno de ladrones y prostitutas acaba imponiéndose a la pedantería institucionalizada. Se debe evitar el engaño de palabras equívocas que no coinciden con significados verdaderos ${ }^{25}$. Ideas nuevas, válidas y necesarias tienen que ser reveladas en un lenguaje claro, vinculado a la vida y al ser uno y distinto del pedante y obsceno, relacionado con falsas apariencias. Literatura, filosofía y ciencia son revestidas de un lenguaje obsceno y blasfemo que expresa no sólo la decadencia socio-política del mundo napolitano sino también la vida religiosa y moral del cristianismo ${ }^{26}$. La religiosidad

22 Cfr. G. Bruno, Candelaio, cit., p. 71: nemo scilicet miretur, nemini dubium sit.

23 Cfr. G. Bruno, op. cit., p. 115: Verba nihil prosunt. Para G. B. Squarotti (ed. Candelaio, cit., pp. 5-6), el Candelaio es uno de los modelos más significativos de la comedia del Renacimiento italiano, cuyo teatro de acción e intriga se caracteriza por un encuentro constante de lenguajes que revela la rapidez del enredo y disolución de diversos sucesos, impulsados por los personajes que son víctimas de la compleja urdimbre tramada. Las diversas formas lingüísticas, cultas y vulgares, manifiestan la polémica comunicación de la sociedad contemporánea con el mismo movimiento veloz que el de los acontecimientos que constituyen la maquinación de fondo. En todo caso, Bruno (op. cit., pp. 17 y 38) se define como Academico di nulla academia, Académico de ninguna de las numerosas academias italianas. Expresándose con claridad y libertad (cfr. Spaccio de la bestia trionfante, cit., p. 551), el Académico de ninguna academia revela el vigor de las cosas, su lado cómico o trágico, y su carácter destructivo y sublime. Por su vitalidad y precisión, prefiere el lenguaje del pueblo al monótono y convencional de los doctos. Anécdotas, bromas triviales y obscenas reflejan las miserias del ser humano.

24 Cfr. G. Bruno, Candelaio, cit., p. 22.

25 Cfr. G. Bruno, op. cit., pp. 34-35 y 78-80.

26 En especial, el dogma de la doble naturaleza de Cristo y el de su presencia real en la Eucaristía. Para Bruno (op. cit., p. 146), la transubstanciación no se efectúa en la ceremonia de la misa, ya que el cuerpo y la sangre de Cristo no se hallan bajo la forma del pan y del vino. La divinidad absoluta no admite encarnaciones. La encarnación de Cristo ha sido aceptada por la credulidad e ingenuidad de los hombres, que son víctimas del temor a la muerte por su ignorancia. El error del cristianismo consiste en una concepción falsa de la relación entre lo humano y lo divino, lo finito y lo infinito, y así se manifiesta en los diversos modos de la presencia del cuerpo de Cristo en la Eucaristía. La religión cristiana nace de la estupidez y locura humana que se revela en el sacrificio eucarístico como función suprema sacerdotal. Cristo es la bestia por excelencia que transforma en bestias a los otros hombres por una intervención ilusoria con lo divino. La transubstanciación y el papel de Cristo como mediador entre lo humano y divino se relaciona con la concepción tradicional de un cosmos finito. Se trataba de explicar cómo el cuerpo de Cristo podía ascender más allá del universo y espacio físico para residir a la derecha del 
exagerada y falsa se reviste de expresiones obscenas, para golpear con ironía la moral cristiana y sus supersticiones y reliquias. La exposición bruniana es extrema y violenta, con construcciones y alusiones grotescas sobre citas bíblicas, fórmulas litúrgicas y convenciones y actitudes sociales ${ }^{27}$. Palabras ingeniosas pronunciadas con brutalidad provocan la risa de esta comedia amarga. En la representación cómica subyace una triste tragedia ${ }^{28}$

La urbe revela la decadencia del hombre, de su mundo socio-cultural y la crisis europea en general. La crisis de la ciudad de Nápoles representa la crisis del siglo. La tragedia de la realidad coincide con un mundo deforme, sórdido e invertido por la ignorancia del sabio y el delirio del prudente. El desorden moral del mundo escinde el ser y aparecer, la esencia y el fenómeno, el alma y el cuerpo. Se defiende el honor aparente, que depende de la estima y opinión de los demás, pero no de lo que somos y hacemos ${ }^{29}$. En este sentido, el asno es un ejemplo de cómo saber explotar la ocasión. Se sobrevalora el dinero, ajeno al vínculo entre virtud y posesión, y es insaciable el interés de ricos y pobres ${ }^{30}$. La riqueza y la pobreza son obstáculos opuestos para el ejercicio de la virtud. Expone el desprecio solitario del filósofo por las supersticiones del amor, la cultura y la alquimia. El caos y la estulticia del mundo se revelan en el ámbito del

Padre y, a su vez, ser capaz de descender a la tierra de acuerdo con una promesa que condenaba el nuevo pacto entre Dios y los hombres. La superación de la Encarnación de Cristo y de la ceremonia eucarística sólo es posible por la concepción infinita del universo. Para Bruno (De immenso et innumerabilibus, cit., liber I, pp. 205-206), el significado auténtico de la relación entre el hombre y Dios sólo se obtiene atribuyendo la infinitud a la criatura divina. En el proceso veneciano (A. Mercati, Il sommario del processo di Giordano Bruno, Città del Vaticano, 1942, pp. 74-76), Bruno desmiente su negación de la transubstanciación o que el pan no se transustancie en carne y de otros sacramentos, y admite no haber asistido a misa y a otros servicios divinos, pero porque estaba excomulgado. Cfr., sin embargo, su concepción de la Eucaristía católica, por ejemplo, en op. cit., liber I, p. 205. Véase, asimismo, V. Spampanato, Vita di Giordano Bruno con documenti editi ed inediti, con una Prefazione di N. Ordine, Paris/Torino, 2000, p. 494. Acerca de la polémica de Bruno contra Cristo y los cultos cristianos, cfr., por ejemplo, G. Bruno, op. cit., liber VIII, p. 316; A. Ingegno, Regia pazzia. Bruno lettore di Calvino, Urbino, 1987, pp. 110-112. Frente a Cusa, Bruno excluye la mediación de Cristo entre la divinidad y el universo. Cfr. la concepción de Cusa acerca de la perfección de Cristo en Nicolai de Cusa, De docta ignorantia, edidit Paulus Wilpert, in Aedibus Felices Meiner, Hamburgi, 1966, III, 5, pp. 32-40. Sobre Cusa, cfr. E. Cassirer, Individuo e cosmo nella filosofia del Rinascimento, Firenze, 1992, pp. 60-70 y 112-117.

27 Cfr. G. Bruno, Candelaio, cit., pp. 101-105 y 108-110.

28 Cfr. G. Bruno, op. cit., p. 135.

29 Cfr. G. Bruno, op. cit., pp. 129-131.

30 Cfr. G. Bruno, op. cit., pp. 63, 80-83 y 95. 
lenguaje y de la acción humana. Describe aspectos y entresijos del mundo que impiden la difusión de la verdad filosófica, tales como los vicios de los hombres, los amores vulgares y sus metáforas insensatas, la pretensión del alquimista de transformar los metales en oro porque cree conocer los secretos mágicos de la naturaleza, la concepción geocéntrica del universo, y el uso pedante de la lengua y de los conceptos. El caos de estas manifestaciones decadentes se revela en las estúpidas ambiciones humanas, en los vanos y vacuos proyectos culturales y en los anhelos del amor vulgar $^{31}$. La virtud, la justicia y el amor brillan por su ausencia. La sociedad carece de orden, comprensión y armonía. La diferencia entre lo justo y lo injusto se diluye sin conciencia, y el destino del hombre se dirige a una situación atroz y sin una salida digna y moral. Su análisis político y social es una consideración lúcida y cruda de las personas y cosas de su mundo. Nada se sustrae a su visión sin escrúpulos ni prejuicios.

Se manifiesta la ruptura del principio de correspondencia entre apariencia y realidad, accidente y substancia. Los personajes se mueven en la asimetría de lo que son, tienen y dicen y lo que quisieran ser, tener y decir $\mathrm{y}$, en virtud de ello, obtienen lo que quieren, su propio beneficio. La dimensión feroz de la vida dirige cada proyecto humano hacia el engaño y el puro instinto animal de supervivencia. Se trata de un universo invertido en el que unos triunfan aprendiendo latín y otros son lacerados y enajenados como sucede con el torpe pedante, el sórdido avaro y el insípido amante, que son lo mismo porque "todo está en todo". El movimiento circular de los astros y del tiempo es un recurso para manifestar la existencia de un principio exterior de equidad, que transciende la virtud y el esfuerzo del hombre. Es necesario el esfuerzo para alcanzar y retener la

31 Sobre la fascinación de amor, cfr. G. Bruno, op. cit., p. 50. Según Bruno (op. cit., pp. 38-41), a expensas de la naturaleza, la religión y la moral han asumido una ley que no acepta la libertad de las relaciones afectivas, pero que admite implícitamente la prostitución y los abortos. Acerca de la crítica sobre la justicia en Nápoles, Venecia y Roma en relación con el tema de la prostitución, véase G. Bruno, op. cit., pp. 140-148. Cuando Bruno describe su periplo por Europa (A. Mercati, op. cit., pp. 104-106), reconoce el error de haber elogiado a herejes -entre ellos, algunos príncipes - por sus virtudes morales. En el proceso veneciano (A. Mercati, op. cit., pp. 102-104), Bruno declara que son necesarias las buenas acciones para la salvación del alma (cfr., por el contrario, De l'infinito, universo e mondi, cit., p. 385; Spaccio de la bestia trionfante, cit., pp. 623-624, 653-654 y 660-663), que el pecado de la carne es un mal menor pero desde una óptica ociosa y mundana, ya que el adulterio es uno de los peores pecados (véase, asimismo, (cfr., sin embargo, De gli eroici furori, en Dialoghi italiani. I. Dialoghi metafisici. II. Dialoghi morali, cit., pp. 930-931), y que no era cierta la analogía que se le atribuía entre el papa y la figura del cerdo (cfr. Cantus Circaeus, cit., p. 195). Sobre estas declaraciones de Bruno, cfr. V. Spampanato, op. cit., p. 495. En cualquier caso, ni los reformados ni los heréticos ni los aristotélicos se identificaron con las ideas cosmológicas, éticas y políticas de Bruno. 
fortuna $^{32}$. La fortuna es ajena a la justicia y a la virtud, ya que dispensa sus bienes a ciegas ${ }^{33}$. Más allá de la traidora fortuna que enloquece sin control $^{34}$, la vicisitud iguala todos los destinos de los hombres, y se presenta como el gozne de la justicia universal, como un principio que abarca y sobrepasa la decisión ética del hombre entre el bien y el mal ${ }^{35}$, entre lo verdadero y lo falso.

Los personajes que simbolizan el deterioro literario, filosófico y científico son condenados por figuras populares de ladrones y rufianes, disfrazados de esbirros para castigar la estulticia de Bonifacio, Bartolomeo y Manfurio, de suerte que la acción de la ley no se ajusta a la estupidez del hombre, cuya vida de engaño y de impulso sensitivo es ajena a la existencia del filósofo que busca la verdad. La esencia de los valores se opone a las vanas y fatuas palabras y a la pura satisfacción física que sólo responde a las exigencias inmediatas de una vida irreflexiva. Junto a la intención corrosiva respecto del orden y estructura de las costumbres tradicionales, se halla la edificación de un futuro en el que se reforme todo proceso literario, filosófico, científico y ético del devenir humano. La eliminación de las instituciones contemporáneas se vincula a una renovación de valores que se opone a las exigencias e instintos inmediatos, primarios, procedentes de una vida condicionada por necesidades físicas y materiales.

\section{La Cena de le ceneri y el De la causa, principio e uno}

En La Cena se recogen sus peores observaciones sobre Inglaterra y su pueblo. Duda de la conducta civilizada de sus amigos y de que el ambiente de la grave disputa entre geocentrismo y heliocentrismo fuera honorable y digno ${ }^{36}$. Aunque reconoce la existencia de verdaderos doctores, los méritos de algunos caballeros, la belleza de las mujeres y la magnífica regencia de Isabel, no puede eliminar la pésima impresión que causaron sus duras descripciones sobre la situación social e intelectual de la mayoría de los ingleses. En virtud de que los doctores afectados no toleran sus ofensas y calumnias y de que se debilita la protección de un noble y co-

32 Cfr. G. Bruno, Candelaio, cit., pp. 150-151.

33 Cfr. G. Bruno, op. cit., pp. 149-151.

34 Cfr. G. Bruno, op. cit., p. 97: Ventura dio, niente senno basta. Cuando se tiene una fortuna favorable, no son necesarias ni la habilidad ni la sagacidad.

35 Según Bruno (op. cit., p. 163), de dos males, debe ser soportado el menor, y de dos bienes, se tiene que elegir el mejor. Véase, asimismo, Aristóteles, Retórica, 4. ${ }^{\mathrm{a}}$ ed., ed. Antonio Tovar, Madrid, 1990, I, 6, 1363a, p. 33.

36 Cfr. G. Bruno, La Cena de le ceneri, cit., pp. 9-10; Spaccio de la bestia trionfante, cit., pp. 549-550. 
nocido señor, Bruno se encierra y retira a la casa de Castelnau, que lo defendió como pudo de la peligrosa tempestad. No se retracta de sus ataques y hace hincapié en todo lo que ha escrito y en la incómoda y molesta descortesía de algunos ingleses ${ }^{37}$. Se corre el rumor de que Bruno ha denigrado toda Inglaterra.

En la reconstrucción del segundo diálogo y del inicio del primer diálogo de La Cena (la cena del Miércoles de Ceniza tuvo lugar en la mitad de febrero de 1584) se debilita la controversia contra la reforma, manifestando una postura más atenuada en la confrontación de Bruno con la cultura y sociedad contemporánea de Oxford, especialmente con Robert Dudley, conde de Leicester (el favorito de la reina Isabel), al que se refiere por su hospitalidad con los extranjeros. La primera ruptura con Leicester guarda relación con el énfasis de su polémica contra la reforma realizada, sobre todo, en el Spaccio, pero ya se manifiesta en el hecho de que Bruno hiciera una revisión de La Cena, en la que denuncia a los doctores de la universidad de Oxford, de la que Leicester era canciller. En la primera visita de Bruno a Oxford, entre el diez y el trece de junio de 1583, muestra su ingenio dialéctico y, en armonía con la política cultural universitaria de Leicester, usa la lógica aristotélica contra la lógica retórico-dialéctica de Pierre de la Ramée representada por John Underhill ${ }^{38}$. La ciencia y la literatura se identifican con la filosofía y la vida, pero no coinciden con los signos y las palabras de matemáticos y gramáticos. El hombre no puede ser objeto de la pretensión cuantitativa y totalitaria de la ciencia y el lenguaje pedante. En La Cena ${ }^{39}$, el diálogo es el lugar de la verdad y su fin es vivificar y agradar la exposición conceptual. La forma dialéctica del diálogo facilita la demostración filosófica. El uso de juegos verbales y de metáforas permite que la seriedad de la exposición filosófica sea más seductora. El diálogo libera la creación lingüística, propaga conceptos e imágenes de la naturaleza del universo, mezcla formas y estilos, y sus variaciones verbales de invención fantástica potencian el discurso filosófico. La imagen polémica del diálogo, con sus elementos cómicos y grotescos, no sólo interrumpe el razonamiento, la demostración y la dialéctica, sino que también recoge todas las actitudes literarias y experiencias filosóficas.

En el De la causa, publicado también en 1584, suaviza su visión de Inglaterra, considerando aptos a sus habitantes para los estudios, armas, humanidad y urbanidad. Sin embargo, en esta tímida revocación se halla

37 Cfr. G. Bruno, Spaccio de la bestia trionfante, cit., p. 549; V. Spampanato, op. cit., pp. 366-369.

38 Cfr. G. Bruno, La Cena de le ceneri, cit., pp. 19-84; G. Aquilecchia, op. cit., pp. 32-35.

39 G. Bruno, op. cit., pp. 7-18. 
presente una apología de La Cena. En el primer diálogo del De la cau$s a^{40}$, plantea el ritmo vicisitudinario de la ciencia y del saber junto con la decadencia de su siglo. Este diálogo se abre con cinco poesías ${ }^{41}$, dedicando la primera a lo principios del universo y a su misión de librar a los hombres del tiempo de tinieblas ${ }^{42}$. Ya en la Proemiale epistola ${ }^{43}$, anticipa esta vuelta a la luz, a la antigua sabiduría, de la que él se siente protagonista y portavoz ${ }^{44}$. El destino de la segunda poesía ${ }^{45}$ es el propio espíritu, y considera la transformación, por beneplácito divino, de la Mente (mediadora entre lo inferior y lo superior) para llegar a la absoluta verdad en su elevada soledad, como acontecerá con el amor heroico en De gli eroici furori. Mantiene una polémica con los pedantes que representan la crisis y decadencia del mundo y que mezclan lengua y filosofía porque creen que la gramática es el camino verdadero del saber. En virtud de que los pedantes han sustituido las cosas por las palabras, su lenguaje carece de sentido. La crisis de la época se manifiesta en el ámbito intelectual, científico y filosófico de los doctores modernos de Oxford, ajenos a las traducciones y a la filosofia antigua de los barbari britanni, cuya especulación transcendía los sofismas carentes de valor filosófico. Si las lenguas son múltiples, las traducciones son esenciales para la libre circulación de los textos. Bruno ${ }^{46}$ hace hincapié en la importancia de las traducciones para propagar el conocimiento de las ciencias. Los traductores deben interpretar los signos lingüísticos, mientras que los filósofos tienen que profundizar en los sentimientos de las palabras y de las traducciones, para poder conocer la filosofía de los antiguos y modernos. El árabe Averroes, gracias a las traducciones, leyó Aristóteles mejor que cualquier griego ${ }^{47}$.

La correspondencia entre lengua y filosofía se ampara en la concepción vital de la materia infinita. La relación del lenguaje con la filosofía es esencial, y la importancia de la grafía y la ortografía se soslaya para acentuar el privilegio de las palabras y los sentimientos, ya que el vínculo entre las palabras y las cosas determina la filosofía y su tradición significativa. Bruno se opone a la concepción aristotélica de la lengua, sobre todo la de los gramáticos y pedantes aristotélicos de la época, por su raíz

40 G. Bruno, De la causa, principio e uno, en Dialoghi italiani. I. Dialoghi metafisici. II. Dialoghi morali, cit., pp. 191-224.

41 G. Bruno, op. cit., pp. 188-190.

42 G. Bruno, op. cit., p. 188.

43 G. Bruno, op. cit., pp. 175-187.

44 G. Bruno, op. cit., p. 187.

45 G. Bruno, op. cit., pp. 188-189.

46 Cfr. G. Bruno, op. cit., pp. 215-216. Véase, asimismo, M. Ciliberto, Lessico di Giordano Bruno, Roma, 1979, 2 vols.

47 Cfr. G. Bruno, op. cit., p. 306. 
filosófica que niega la existencia de la multiplicidad. Los pedantes son los responsables de la crisis de todo el saber, del que se han apoderado, provocando su corrupción. Hay que combatir esta ignorancia trágica que ha oscurecido todo el pensamiento europeo. La alternativa de Bruno es una filosofía que ilumine a los hombres en un tiempo de tinieblas filosófico-científicas. La decadencia universal se inscribe en la historia cíclica de la verdad eterna, en la vicisitud de sabiduría antigua y cristianismo, de luz y tinieblas. Las ciencias, la filosofía y las costumbres han llegado al punto más bajo de la rueda del tiempo. En el De la causa ${ }^{48}$, afirma la existencia de múltiples recorridos filosóficos a los que corresponde una diversidad de lecturas filosóficas y de tradiciones terminológicas. Una misma palabra significa cosas y pensamientos distintos según el sistema filosófico al que pertenezca ${ }^{49}$. Esta pluralidad filosófica y terminológica circula con libertad y concurre en el conocimiento de la naturaleza. La filosofía que más profundice en este único objetivo será la más legítima, y la menos próxima a la pedante censura. Para tomar posición en la diversidad filosófica es necesario el reconocimiento de múltiples lenguas al igual que de sentimientos. Bruno indaga las claves del lenguaje aristotélico para volverlo a definir al amparo de su filosofía. Ésta debe liberarse de la esclavitud de las palabras con el fin de dominarlas.

\section{El Spaccio de la bestia trionfante}

El Spaccio (1584) es una obra ética al amparo del "divino sol intelectual". Con una fantasía bizarra defiende la "sinceridad, simplicidad, verdad" de sus pensamientos, cuya conclusión definitiva se establecerá en otros diálogos ${ }^{50}$. El Spaccio es un diálogo mitológico que plantea el fin de las religiones y la llegada de una divinidad inmune a los vicios y a la bestialidad y de la que procede la verdad. Para alcanzar una auténtica y radical reforma del universo, todo debe ser destruido: conceptos, dogmas, supersticiones, engaños e ideales de la tradición hebraico-cristiana. Es una demolición de toda la enciclopedia del decir ético, religioso y político, de todas las actitudes e ideas con escaso valor intelectual. Es una condena a la frivolidad, a los comportamientos de moda de los hombres, al absurdo lógico y racional del lenguaje vanidoso e insensato de ritos y cultos religiosos, tanto el de las ceremonias del sacrificio hebraico cuanto el de la veneración cristiana de la celebración de la muerte de Cristo.

\footnotetext{
48 G. Bruno, op. cit., pp. 257-259.

49 Cfr. G. Bruno, op. cit., pp. 254-288.

50 Cfr. G. Bruno, Spaccio de la bestia trionfante, cit., pp. 551 y 553-555.
} 
En el Spaccio, la justicia se fundamenta en el mérito y la virtud del hombre, y se establece la relación entre ley y verdad desde una óptica anticristiana ${ }^{51}$. La burla se dirige hacia el Dios hebraico y cristiano y el caos de sus dogmas y metáforas bíblicas. Los reformados, los secuaces de Lutero, son los protagonistas de la crisis moral en el marco de la vicisitud de sabiduría luminosa e ignorancia umbrátil. La decadencia del siglo infeliz es universal y abarca toda la realidad filosófica, religiosa y civil, ya que ha alcanzado el punto inferior de la rueda del tiempo, vaticinando una antigua y nueva filosofía y sabiduría. El Spaccio refleja el debate religioso y teológico de los años ochenta en Inglaterra, y se opone al período tenebroso e ignorante de los pedantes reformados que niegan la ley y la justicia y destruyen la paz de la convivencia humana. Teniendo presente la crisis radical de la sociedad inglesa, se sitúa la reforma interior del hombre y el problema de la ley y de la justicia.

En el primer diálogo ${ }^{52}$, el concepto de destino coincide con la justicia divina y absoluta en la que se reconoce lo verdadero. La solución conceptual de la justicia es filosófica, ya que la filosofía establece los límites del conocimiento y halla la relación exacta entre el hombre y lo divino, tanto en el ámbito civil cuanto en el religioso ${ }^{53}$. El cristianismo representa la inversión de la verdad especulativa, moral y religiosa de la mitología antigua. Se niega la divinidad de Cristo, el ser hombre e hijo de Dios, y su gloria obtenida junto al Padre. El cristianismo es un enigma para los hombres porque es ajeno a los valores que simbolizan la noción correcta de perfección humana ${ }^{54}$. La personalidad de Cristo se caracteriza por un insaciable deseo de ambición y gloria, y el origen de sus prodigios es demoníaco. Tanto la doctrina del Evangelio como las ceremonias derivadas de él son fuente de ilusiones que han subyugado a toda la humanidad. Se trata de cerrar este período de tinieblas y de encontrar una alternativa al anuncio evangélico de salvación eterna, mediante una transfor-

51 Cfr. G. Bruno, op. cit., pp. 625, 657 y 760. El núcleo de la investigación sobre el Spaccio de A. Ingegno (La sommersa nave della religione. Studio sulla polemica anticristiana del Bruno, Napoli, 1985, p. 9) es la conciliación del valor de lex sustentado por el cristianismo con la teoría del horóscopo de las religiones y con la exigencia de verdad de una nueva religión. Respecto de la intención crítica del Spaccio, cfr. E. Garin, La cultura filosofica del Rinascimento italiano. Ricerche e documenti, 2." ed., Firenze, 1991, p. 175: "Sotto un velo molto trasparente si combattono la chiesa di Roma, il pontefice (era Alessandro VI), gli ordini monastici, i sacerdoti, e la critica investe anche certi aspetti dogmatici, e taluni modi di intendere la Scrittura".

52 G. Bruno, op. cit., pp. 571-645.

53 Cfr. G. Bruno, op. cit., p. 794. Sobre la concepción civil y religiosa del Spaccio, cfr. A. Ingegno, op. cit., passim.

54 En el De immenso et innumerabilibus (cit., liber VIII, p. 291), se opone a los semihombres y semibestias que han llegado a ser objeto del culto cristiano. 
mación cósmica dotada de un preciso valor filosófico. Esta luz se revela en la coincidencia de multitud de aspectos astronómicos y astrológicos. Bruno se plantea el carácter absoluto del destino y la certeza de que nada puede escapar del decreto de la providencia divina, aunque ésta no deje de enviar auténticos mensajes celestes al hombre. Se ha perdido la relación correcta entre la diversidad del mundo humano y la indistinción de la divinidad suprema. Es necesario un nuevo concepto de justicia en el que lo divino y lo humano se vinculen a sus adecuados términos. La investigación de este vínculo es el objeto de la sabiduría. La ley suprema de la realidad es el destino de la mutación de cada ser real que alumbra el significado de la vida civil y la raíz del error cristiano.

En el diálogo segundo ${ }^{55}$, investiga los medios por los que se transmite la divinidad, y considera que la ley y la justicia son los fines del mundo humano y pueden armonizarse con la voluntad divina sin menoscabarla. Esta voluntad se manifiesta de algún modo en el hombre, y está destinada a realizarse, aunque sólo se comprenda de una manera imperfecta. Para alcanzar un cumplimiento pleno en el mundo humano, la ley y la justicia deben vincularse a la fuerza y el esfuerzo. El hombre puede concretar los signos y fines últimos a los que no tiende la justicia absoluta y actuar de acuerdo con los recursos de los que dispone para garantizar su éxito. $\mathrm{La}$ certeza de la providencia y de la distancia entre lo humano y lo divino permite establecer el contenido de las leyes y de la justicia otorgada a los hombres. La ley civil se regula sobre el horizonte de la ley natural y divi$\mathrm{na}^{56}$. Lo justo y natural son los contenidos de la ley, cuyo correcto cumplimiento es por obra de la justicia. La ley rige y la justicia dispone. El fin de la justicia es la utilidad y el bien común de la sociedad, el buen funcionamiento de las relaciones entre los ciudadanos. La unificación de ley civil y religiosa y de sus fines conlleva un significado político en los objetivos religiosos. La justicia revela la adaptación e inclinación de lo absoluto hacia lo humano ${ }^{57}$. Es absurda una propuesta divina de ley que sea imposible de ser cumplida por el hombre ${ }^{58}$. La comunicación civil es el fin fundamental de la ley. El funcionamiento correcto de la ley y de su vínculo con la justicia depende de la realización de las acciones humanas en su ámbito colectivo, cuyo valor es el origen de la convivencia civil, junto con las diferencias individuales y la diversidad de costumbres y temperamentos. La solución metafísica de la justicia culmina en las sociedades caracterizadas por actos heroicos, cuyas leyes tienden a la con-

\footnotetext{
55 G. Bruno, Spaccio de la bestia trionfante, cit., pp. 646-724.

56 Cfr. G. Bruno, op. cit., p. 652.

57 Cfr. G. Bruno, op. cit., p. 654.

58 Cfr. G. Bruno, op. cit., pp. 660-661.
} 
versación civil y a la concordia humana. Teoría y práctica, razón y voluntad, deben conciliarse en el mundo del hombre, del que depende la constancia y firmeza para que se cumpla la justicia. La ley tiene que ser útil para la sociedad y poseer un valor absoluto y autónomo en el mundo humano, con el fin de que se constituya en una obligación moral de los hombres. Desde una óptica humana, civil y natural, la ley, la justicia, la concordia y la religión son necesarias para alcanzar la renovación del mundo y el progreso de la ciencia y la filosofía, del saber en general ${ }^{59}$. La sinceridad, simplicidad y verdad de los justos y sabios deben combatir el mundo adulterado y falso de los perversos y estúpidos.

El mundo contemporáneo de Bruno está invertido, porque los significados de las palabras no obedecen a su sentido específico y la claridad del lenguaje se ha perdido en el engaño, en la distorsión y en la transfiguración de las cosas. Se reflexiona sobre la crisis de los órdenes del mundo bajo la ignorancia de los ambientes académicos y religiosos, cuya pedantería ha provocado la crisis radical del saber, sobreponiendo las palabras a las cosas. La mistificación de las cosas e inversión de los significados de las palabras ha sido llevada a cabo por el cristianismo y el humanismo. Éste se ha transformado en pedantería, cuya decadencia es letal para el saber. El significado de las palabras debe liberarse de la esclavitud gramatical. El purismo lingüístico y formal, fundamentado en la apariencia de las palabras, origina la oposición entre las palabras y las cosas. Las reglas, la autoridad, las normas de los gramáticos y pedantes pretenden frenar la novedad de la filosofía. La ontología bruniana de la materia infinita se opone al lenguaje universal de los pedantes, porque la realidad no se agota de una vez por todas, su vida infinita no puede ser expresada por el alfabeto de los ignorantes. El lenguaje debe transcender el ejercicio servil y exacto que pretenden los gramáticos tradicionales y tiene que configurarse en un progreso infinito de acuerdo con la concepción cambiante de la realidad. La filosofía debe acabar con la decadencia lingüística y conceptual del ciclo hebraico-cristiano (incluida la reforma de Lutero y Calvino) y restituir la antigua conexión natural entre cosas y palabras para que la divinidad, la naturaleza y los hombres se comuniquen entre $\mathrm{si}^{\prime}{ }^{6}$. La gramática, la sintaxis, la estructura dialógica, la retórica, todos los

59 Cfr. G. Bruno, op. cit., p. 703.

60 Cfr. G. Bruno, op. cit., p. 551. Las persecuciones de los pedagogos calvinistas permiten conjeturar que Bruno abandona Ginebra en 1579 por sus sentimientos adversos hacia la reforma. En los diálogos italianos, sobre todo en el Spaccio, critica las diversas herejías y en especial la radicalidad y fundamentalismo de Calvino y sus secuaces. Sobre el lenguaje del Spaccio y su relación con la reforma ética y religiosa, cfr. G. B. Squarotti, Parodia e pensiero: Giordano Bruno, Milano, 1997, pp. 57-65 y 95-175. Respecto a la oposición de Bruno a la Reforma protestante, cfr. S. Ricci, La fortuna del pensiero di Giordano Bruno, 1600-1750, con 
elementos de la escritura deben estar al servicio de la concepción de un universo infinito, en que la verdad domina y la vida se halla en cualquier punto cósmico. El léxico de Bruno es fruto de palabras doctas, conceptos obscenos, dialectos, términos inventados y procedentes de diversos lenguajes. La lengua es utilizada como si fuese un material plástico ${ }^{61}$. En el Spaccio $^{62}$, literatura y filosofía se sostienen y nutren entre sí. Lo cómico y divertido para la mayoría se concilia con la oculta seriedad para la minoría. Ley, verdad, religión, política y filosofía tienen que conciliarse con la sabiduría universal, para comprender y descifrar el libro de la infinita naturaleza y hablar con la divinidad mediante un lenguaje natural, ajeno a las letras del alfabeto ${ }^{63}$. En el Spaccio ${ }^{64}$, se opone a los gramáticos y pedantes lingüísticos y defiende el uso libre y funcional de la lengua. Propone un lenguaje natural anclado en el ser de las cosas, en su propio nombre, de tal modo que las palabras y los conceptos expresen la verdadera naturaleza, el ser de cada cosa, y así restituir la función primaria del lenguaje, perdida en la babel de los pedantes, que separaron las lenguas de la naturaleza.

En el Spaccio consolida, desde una óptica ética, la ontología de la materia infinita del De la causa, de tal manera que las jerarquías, reglas, normas e imitaciones se despedazan para dar paso a la libertad, creatividad e invención. En la segunda parte del tercer diálogo ${ }^{65}$, el Olimpo reformado representa el espacio ejemplar de orden, medida, moralidad y naturaleza, la reconstitución ética en cada aspecto del cosmos, después de tantos siglos de imágenes inmorales exaltadas como acciones heroicas por el poder de la divinidad. El destino de la reforma moral de los cielos es la sustitución de las imágenes celestes por imágenes de virtud. Deben desterrarse las encarnaciones celestes de los vicios y los eventos del insignificante mundo cotidiano de los hombres. Los comportamientos divinizados por la religión son, en realidad, inmorales, vanos y contrarios a la ética natural y social. Mitología y filosofía se fusionan y disuelven para

una Prefazione di E. Garin, Firenze, 1990, p. 305. Sobre las relaciones de Bruno con el calvinismo, con Lutero y con el catolicismo, cfr. G. Gentile, Giordano Bruno e il pensiero del rinascimento, cit., pp. 81-100. Acerca de la postura de Bruno respecto del cristianismo, véase A. Guzzo, Giordano Bruno, Buenos Aires, 1967, pp. 52-56.

61 Cfr. G. Bruno, op. cit., pp. 821-822; N. Ordine, La cabala dell'asino. Asinità e conoscenza in Giordano Bruno, con una Prefazione di Eugenio Garin, Napoli, 1996, p. 149.

62 G. Bruno, op. cit., pp. 549-570.

63 Cfr. G. Bruno, De magia, en Jordani Bruni Nolani, Opera latine conscripta, cit., III, pp. 411-412.

64 G. Bruno, op. cit., pp. 551-553.

65 G. Bruno, op. cit., pp. 747-802. 
investigar la verdad del universo. Se ha perdido la regla moral consignada en la mitología porque los especialistas del carácter alegórico del mito se han distanciado de los ejecutores de sus preceptos que tienden a dar un sentido literal al mito. En este sentido, el cristianismo es una fábula que no guía a la mayoría, puesto que ha invertido los fundamentos de la moral. Es una fábula que ha pervertido la regla de la verdad y de la justicia, perturbando los preceptos de la recta razón y de la moralidad, difundidos entre los pueblos ${ }^{66}$. La reforma de los dioses en el cielo es el modelo para la transformación ética y social de los hombres, y es sólo un espectáculo para simbolizar el triunfo de la verdad del universo infinito, de la unidad y de los innumerables mundos. En virtud de que la ilusión y la superstición no pueden ser los regentes absolutos de la vida humana, las constelaciones del Zodíaco deben ser sustituidas por la sindéresis o capacidad para juzgar con rectitud ${ }^{67}$. La reforma del cielo conllevará la transformación del mundo interior del hombre ${ }^{68}$. Hay, pues, una huella ética y moral en la filosofía de la naturaleza y en la cosmología de Bruno. La dignidad en el mundo y la intuición de lo infinito e inconmensurable se vinculan a la actitud heroica del hombre. La divinidad se contrae en cualquier parte singular de la naturaleza, y el hombre se comunicará con ella cuando comprenda que no la puede alcanzar en su carácter absoluto sino en su escisión por el mundo. Esta limitación de lo divino media entre el hombre y aquello que lo supera ${ }^{69}$.

En el Spaccio ${ }^{70}$, un sentido anticristiano del universo y del hombre se manifiesta en el destino de las almas individuales y en la figura de Cristo. El cristianismo conlleva la decadencia y gran crisis del mundo por su ruptura con los vínculos entre Dios y el hombre. En el Spaccio, realiza una crítica radical al diluvio universal, rechaza la antigüedad de las Escrituras y el modelo cristiano de creación, y acepta el poligenismo y la generación espontánea de los hombres, ya que el emparejamiento de hombres y mujeres no es la única causa generativa del ser humano ${ }^{71}$. La superioridad de los habitantes del Nuevo Mundo se revela en su piedad y humanidad. En el tránsito de la naturaleza a la civilización y en las transformaciones de las

66 Cfr. G. Bruno, De immenso et innumerabilibus, cit., liber VI, pp. 171-172; Spaccio de la bestia trionfante, cit., pp. 785-786.

67 Cfr. G. Bruno, Spaccio de la bestia trionfante, cit., p. 561.

68 Cfr. G. Bruno, op. cit., pp. 611-612.

69 Sobre la relación de la divinidad con el hombre, cfr. G. Bruno, op. cit., pp. $777-$ -787 y $794-796$.

70 G. Bruno, op. cit., pp. 624-626 y 660-663.

71 Acerca de que el género humano no procede de Adán, cfr. A. Guzzo, op. cit., p. 52. Sobre el monogenismo y el poligenismo, cfr. B. Levergeois, Giordano Bruno, Le Flèche, 1995, pp. 293-294. 
naciones europeas, la división de la tierra, mar y aire y las conquistas coloniales son los elementos negativos que el ocio defiende frente al esfuerzo ${ }^{72}$. La "santa ignorancia" disuelve el conocimiento de la naturaleza con pedantes elucubraciones y destruye el diálogo y la paz de los pueblos ${ }^{73}$. Ninguna religión puede responder a este crítico momento histórico, ya que se ha agotado el ciclo hebraico-cristiano, y este mundo tiene que abrirse a una renovatio, a un nuevo tiempo universal, siendo Bruno el restaurador de su saber secreto. Se agotan las tinieblas cristianas y se aproxima una nueva religión, en la que se vinculen la enseñanza civil de los romanos ${ }^{74}$ y la natural de los egipcios ${ }^{75} \mathrm{y}$ en la que se restituya, por la magia y la naturaleza, la armonía del hombre con el hombre y la divinidad.

72 Cfr. G. Bruno, op. cit., pp. 728 y 733.

73 Cfr. G. Bruno, op. cit., pp. 623, 626, 661 y 803-805.

74 Cfr. G. Bruno, op. cit., pp. 659-660. La razón y voluntad del pueblo romano produjeron actos heroicos que edificaron una vida civil basada en valores supremos.

75 Bruno (op. cit., p. 795) justifica la idolatría de la religión egipcia y antigua por su culto a animales y dioses vivientes frente a la adoración cristiana a hombres muertos, que son considerados santos por este peculiar politeísmo. Los mitos religiosos de los antiguos se adaptaron a la capacidad cognoscitiva del hombre, pero la persistencia de su carácter alegórico y las interpretaciones literales originaron una religión alejada de la ley moral. En este sentido, los hebreos corrompieron los mitos egipcios. Son frecuentes las críticas mordaces de Bruno (por ejemplo, La Cena de le ceneri, cit., p. 39) a la filosofía académica y los elogios a la secreta sabiduría de la Antigüedad. Tinieblas, ignorancia, barbarie y cristianismo se oponen a luz, sabiduría, civilización y religión egipcia. Los infelices siglos de tinieblas se deben al ocaso de la antigua sabiduría egipcia, que era ajena a la fractura de cielo y tierra porque hombres y dioses se comunicaban entre sí por la mágica acción natural de su lenguaje. El rechazo de Bruno a la tradición hebraico-cristiana y la exaltación a la greco-romana, marcó su tendencia a favor de la cultura y civilización egipcias y a considerar el origen egipcio de algunas enseñanzas hebreas. Los hebreos, lejos de ser el pueblo elegido por Dios, representan la gente más ignorante y supersticiosa de Oriente. Sus creencias y ritos son desviaciones de los egipcios, por lo que carecen de autonomía y de una misión profética especial. El judaísmo no es una religión excepcional sino que hereda las supersticiones de Egipto, de tal modo que el Moisés de Bruno aparece como discípulo corrupto de Hermes. En el proceso veneciano (A. Mercati, op. cit., pp. 86-87), sostiene que Moisés era experto en la magia de los egipcios y fue capaz de superarla por su soledad contemplativa durante casi cuarenta años. La magia de Moisés es la absoluta, legítima y ajena a la superstición, porque su objeto es el conocimiento de los enigmas y fuerzas de la naturaleza, por la observación de las disposiciones temporales del cielo, por la acción de una materia sobre otra y por la vinculación de los principios pasivos inferiores a los activos superiores. Sin embargo, para Bruno (Spaccio de la bestia trionfante, cit., pp. 782-783 y 791-792) la sabiduría de la Cábala procede de los egipcios que instruyeron a Moisés en la magia. El desvío cosmológico y religioso se manifiesta en la colisión entre diferentes y falsas imágenes de la divinidad. En el De immenso (De immenso et innumerablibus, cit., liber VI, pp. 170-172), se vincula el copernicanismo a la religión egipcia -recogida por Bruno del Asclepio-, por su íntima conexión con la cosmología presocrática y con la palingenesia cósmica. El copernicanismo juega un papel fundamental en la obra de Bruno y sin él 
La religión no puede recluirse en una rígida condición abstracta y uniforme sino que debe medirse con las mutaciones y el paso del tiempo. A pesar de algunas degeneraciones del culto religioso, por ejemplo la superstición ${ }^{76}$, la religión es necesaria como práctica educativa, y tiene que estar al servicio del estado y del diálogo civil. El proyecto de una sociedad equilibrada y justa requiere que la religión se someta al poder político ${ }^{77}$. Para favorecer el camino de la civilización, las leyes del estado y de la religión deben fundirse, como lo demuestra la experiencia positiva del pueblo romano ${ }^{78}$. El poder político y el culto religioso tienen que coincidir para favorecer la misión de los hombres en la sociedad y el equilibrio y la paz en una Europa lacerada por las guerras de religión. La emanación de leyes y de culto religioso permitirá la "civile conversazione"79. La realización de objetivos mide la eficacia de la religión. La superioridad de un culto religioso no depende de ningún elemento específico sino de su contribución a la conversación en la comunidad política. La voluntad y el pensamiento del pueblo se asientan en creencias, en la religión como institución social, en las ideas morales, la vida y la historia cotidianas, en la fe o ámbito de lo irracional, en la pasión. El conocimiento de la verdad, libre de contradicciones, es propio del sabio, cuya contemplación racional del universo conlleva la negación absoluta de la fe.

no se puede comprender el sentido del hermetismo en su cosmología y metafísica. En el Spaccio, la reforma del cielo y la relación de la estructura astrológica con la teoría del horóscopo de las religiones alcanzan su pleno sentido a la luz del heliocentrismo copernicano. El Hermetismo influye en la nueva concepción de la naturaleza y del universo que son la manifestación infinita de la divinidad. Sin embargo, esta visión del mundo y del hombre no puede entenderse sin la interpretación bruniana del copernicanismo, cuya importancia es insoslayable. Cfr. E. Garin y otros, El hombre del Renacimiento, Madrid, 1990, p. 179: "Hermetismo significa sobre todo exaltación del hombre: un hombre que no será otro que el dios hermético Anthropos humanizado -'gran milagro', como repetía en su célebre discurso Giovanni Pico della Mirandola-. Hermetismo es una visión de la realidad como vida universal y amor universal, luz (e inteligibilidad) universal". Acerca de la idolatría de los antiguos, véase, asimismo, N. de Cusa, op. cit., I, 25, pp. 104-108. Sobre los límites legítimos de la idolatría, cfr. G. Bruno, De gli eroici furori, cit., pp. 1077-1078; De immenso et innumerabilibus, cit., liber VIII, pp. 286-318. Para Bruno (De gli eroici furori, cit., pp. 1081-1082), el hombre no puede dar gloria a Dios, ya que éste retrocedería al rango de ídolo o a una criatura elevada a la categoría de divinidad. Bruno establece una correspondencia entre la imagen de Cristo y la idolatría del culto a su persona, y critica los falsos ritos de su época que se mantienen en el ámbito de una vida infernal. Respecto de este tema, cfr. A. Ingegno, Regia pazzia. Bruno lettore di Calvino, cit., pp. 90-96 y 98-100.

76 Cfr. G. Bruno, Spaccio de la bestia trionfante, cit., p. 792.

77 Cfr. G. Bruno, op. cit., p. 659.

78 Cfr. G. Bruno, op. cit., pp. 659-660.

79 Cfr. G. Bruno, op. cit., pp. 656-657. 
En el Spaccio $^{80}$, la verdad suprema se identifica con la unidad, regente en el universo, y la verdad sensible, captada por el entendimiento, coincide con la unidad cósmica.

Ella es delante de las cosas, por modo de causa y principio, mientras por ella las cosas tienen dependencia; es en las cosas, y es su misma substancia, mientras por ella tienen la subsistencia; es después de todas las cosas, mientras por ella se comprenden sin falsedad. Es ideal, natural y nocional; es metafísica, física y lógica. Por lo tanto, es la verdad sobre todas las cosas; y lo que está sobre todas las cosas, aunque sea concebido según otra razón y denominado de otra manera, sin embargo aquello en substancia necesita que sea la misma verdad. (...) Pero ciertamente esta [verdad] que ves sensiblemente y que puedes captar con la alteza de tu entendimiento, no es la suma y primera, sino cierta figura, imagen y cierto resplandor de aquélla,... ${ }^{81}$.

Junto a la verdad, la providencia interviene en las cosas y principios sumos por la libertad y necesidad, que es el modelo del universo ${ }^{82}$. La realización material de este paradigma se genera por la prudencia, el fluir temporal en los entes cósmicos que se dirige a la sabiduría adquirida, "vulgarmente llamada metafísica, la cual considera los universales de todas las cosas que caen en el conocimiento humano" 83 . Desde la óptica civil y social, la coincidencia de necesidad y libertad es la solución a la crisis religiosa de la época. La coincidencia en Dios de libertad y necesidad se realiza en el mundo humano, ya que el desarrollo de las facultades intelectuales permite establecer la relación entre el hombre y lo divino. Si la posible justicia humana se inscribe en la esfera de lo necesario, las acciones de los hombres se vinculan a un horizonte superior en el que se

80 G. Bruno, op. cit., p. 646.

81 G. Bruno, op. cit., p. 647: "Essa è avanti le cose, per modo di causa e principio, mentre per essa le cose hanno dependenza; è nelle cose ed è sustanza di quelle istessa, mentre per essa hanno la sussistenza; è dopo tutte le cose, mentre per lei senza falsità si comprendeno. È ideale, naturale e nozionale; è metafisica, física e logica. Sopra tutte le cose, dunque, è la verità; e ciò che è sopra tutte le cose, benché sia conceputo secondo altra raggione, ed altrimente nominato, quello pure in sustanza bisogna che sia l'istessa verità. (...) Ma certo questa [verità] che sensibilmente vedi e che puoi con l'altezza del tuo intelletto capire, non è la somma e prima, ma certa figura, certa imagine e certo splendor di quella,...”. Cfr. trad. I. Gómez de Liaño, op. cit., p. 93.

82 Cfr. G. Bruno, op. cit., pp. 648-649. La insensata providencia divina no se halla en las cosas del mundo ni guarda relación con la naturaleza y los hombres.

83 G. Bruno, op. cit., p. 648: “(...) nomata volgarmente metafisica, la quale considera gli universali de tutte le cose che cascano in cognizione umana...”. Cfr. trad. I. Gómez de Liaño, op. cit., p. 95. 
identifican necesidad y libertad ${ }^{84}$. La fortuna no ocupa un lugar determinado en el cosmos y reclama el sitio de Hércules que es, por el contrario, asignado a la fortaleza para que rija la verdad, la ley y el juicio, tutele todas las virtudes, invite al esfuerzo y domine la rueda del destino ${ }^{85}$. El elogio del nuevo significado del trabajo y el esfuerzo surge de la relación del hombre con la naturaleza, y vislumbra cierto desdén a lo transmitido por herencia ${ }^{86}$. El hombre deberá comprometerse con el trabajo según el ingenio y cualidades concedidas por la fortuna natural. El trabajo es lo único que puede satisfacer al hombre. Los que sólo gozan de lo obtenido por el esfuerzo de los progenitores, se asemejan al alma de los animales, su vejez no será agradable por la inutilidad del declive de su vida, y su muerte sofocará una vida sin vivencia alguna. Los obstáculos pasajeros no deben desalentar, porque toda iniciativa es posible si quiere hacerse, $\mathrm{y}$ no es tan relevante el resultado cuanto el máximo esfuerzo y el sentimiento de dignidad y elogio propios del vencedor y no de la fortuna ${ }^{87}$.

La finalidad de la filosofía moral de Bruno ${ }^{88}$ es iluminar y jerarquizar las virtudes y los vicios o "formas primeras de la moralidad"; el objeto de su ética es instituir, regular y ordenar las leyes, las costumbres y las religiones, no sólo de este mundo sino también de los otros mundos semejantes al nuestro, para armonizar las acciones y los afectos en la convivencia humana, cuya libertad queda garantizada por la ley a la que se halla sometida. Y si en el Candelaio no distingue el mérito de la fortuna, en el Spaccio se afirma el valor y el reconocimiento del esfuerzo. Mediante el trabajo se pueden dominar los eventos de la fortuna y afrontar los males con empeño y fervor. La condición animal del hombre es anterior a la diferencia entre el bien y mal y entre mérito y pecado, y se representa por la pretensión del Ocio de ocupar el lugar del esfuerzo. El Ocio ${ }^{89}$ sólo posee relativa utilidad mediante la acción y ocupación del hombre. La ideología del Ocio simboliza la ignorancia. El Ocio tiene una visión inmóvil del mundo, en el que los hombres viven una indigna condición de igualdad basada en el estancamiento y lo inoperante. Si cada cosa permanece siempre idéntica a sí misma, no existirá la posibilidad de diversidad y modificación. La quie-

${ }^{84}$ Acerca de la relación entre necesidad y libertad en el Renacimiento, cfr. E. Cassirer, op. cit., pp. 119-195 y 226-227.

85 Cfr. G. Bruno, op. cit., p. 699.

86 Cfr. G. Bruno, De monade, numero et figura, en Jordani Bruni Nolani, Opera latine conscripta, cit., I, 2, pp. 424-425.

87 Cfr. G. Bruno, La Cena de le ceneri, cit., p. 63.

88 G. Bruno, Spaccio de la bestia trionfante, cit., pp. 554 y 702-703

89 Sobre el ocio, cfr. G. Bruno, op. cit., pp. 726-730 y 741-745. Bruno considera la historia como una alternancia de luz y tinieblas. Cfr., por ejemplo, De la causa, principio e uno, cit., pp. 246-247; Sigillus sigillorum, en Jordani Bruni Nolani, Opera latine conscripta, cit., II, 2, p. 213: Nihil sub sole novum. 
tud sólo puede ser trastocada por las vicisitudes del esfuerzo que provocarán mecanismos de diferenciación, acción y transformación, junto a los que se hallan la injusticia y la desigualdad, que pueden combatirse en el camino de la civilización. El Ocio no permite el desarrollo del conocimiento y de la civilización, y sus seguidores vegetan en la incapacidad de saber preguntarse por sí mismos y por la naturaleza.

En definitiva, la filosofía debe abordar los problemas teológicos sobre la base de los límites del conocimiento y en relación íntima con la moral para fundamentar la vida social del hombre. El horizonte del hombre es la verdad, providencia y sabiduría entendidas como el grado supremo de lo absoluto. Entre la coincidencia de providencia, verdad y sabiduría en lo absoluto y su diversidad en lo empírico se hallan la ley y la justicia como instrumentos concretos por los que la justicia absoluta encuentra su realización. A pesar de que la justicia y la ley son medios exclusivos del mundo del hombre, mantienen una relación con la voluntad divina, que se escinde en múltiples rostros para hacerse visible al hombre y, a su vez, los unifica en su ser supremo.

En la sabiduría providencial, el ojo y la luz son idénticos, puesto que el ojo es por sí y la verdad es en sí. Esta sabiduría esencial no es accesible en su totalidad, no puede ser simbolizada y es la causa de la sabiduría adquirida por la contemplación del universo ${ }^{90}$, que es "ilustrada en los ingenios, comunicada por las palabras, digerida por las artes, refinada por las discusiones, delineada por las escrituras; ;..."91. Este saber es especular porque "no es el uno, no es el ente, no es la verdad; sino del uno, del ente, de la verdad; para el uno, para el ente, para la verdad; por el uno, por el ente, por la verdad; en el uno, en el ente, en la verdad; desde el uno, desde el ente, desde la verdad"92. La máxima expresión de lo absoluto es una guía visible hacia lo invisible.

(...) mientras aquella [Sofía], presente en ningún lugar, en ningún lugar ausente, les grita y propone ante los ojos del sentimiento todas las cosas y efectos naturales a través de la escritura, y les entona en el oído de la mente interna por medio de las especies concebidas de las cosas visibles e invisibles ${ }^{93}$.

90 Cfr. G. Bruno, op. cit., pp. 649-651.

91 G. Bruno, op. cit., p. 650: “(...) illustrata nell'ingegni, communicata per le paroli, digerita per l'arti, repolita per le discussioni, delineata per le scritture;...". Cfr. trad. I. Gómez de Liaño, op. cit., p. 96.

92 Ibidem: “(...) non è l'uno, non è l'ente, il vero; ma de l'uno, de l'ente, del vero; a l'uno, a l'ente, al vero; per l'uno, per l'ente, per il vero; nell'uno, nell'ente, nel vero; da l'uno, da l'ente, dal vero". Cfr. trad. ibidem.

93 G. Bruno, op. cit., p. 652: “(...) mentre quella [Sofia] gli crida, in nullo luogo presente, da nullo luogo absente, proponendogli avanti gli occhi del sentimento per 
El ojo del sentimiento y de la mente recibe la huella de la sabiduría divina por el sonido de su lenguaje natural. Desde el punto de vista cognoscitivo, la unidad suprema se comunica con el hombre por la condición de escisión en sus diversos aspectos. Lo que es indistinto en la unidad se diferencia en los seres individuales y sensibles. No es posible alcanzar el conocimiento de la indistinción absoluta y de su diversidad en la singularidad si la verdad, providencia y sabiduría divinas son entendidas como modelos ideales. Bruno renuncia a la propuesta de valores absolutos y presenta el carácter cíclico de la verdad, providencia y sabiduría desde una óptica empírica, planteando la posibilidad de diferenciarlas en su realización gradual. El problema reside en el desarrollo y conciliación infalible de la providencia absoluta con cada ser individual, así como la utilización de una sabiduría humana que no sólo es inferior desde el punto de vista ontológico sino que puede limitar y ocultar los conceptos de verdad y justicia. Por las leyes y la justicia, los hombres son capaces de ascender de su naturaleza bestial a su condición heroica, dirigiéndose hacia la divinidad. La sabiduría humana dialoga con los mensajes de la divinidad por la existencia de un ámbito intermedio entre lo absoluto y lo empírico, en que se garantiza la aplicación concreta del destino de la mutación. El destino encuentra su realización por la ley y el juicio, y su acción efectiva se manifiesta en la justicia terrena. La verdad, la sabiduría y la prudencia se vinculan a una esfera intelectual que explica la realización de la comunicación entre lo humano y lo divino. Se trata de desvelar los actos de la providencia divina que se inclinan a satisfacer las necesidades peculiares de los hombres. Lo absoluto se amolda a lo humano con el fin de que se hallen el sentido y los modos de su acción.

\section{La Cabala del cavallo Pegaseo}

La Cabala (1585) es el segundo diálogo moral y puede considerarse un apéndice del Spaccio. En este diálogo, se burla de la ignorancia y superstición que agradan al pueblo pero no a los sabios ${ }^{94}$. En la Cabala $^{95}$, lo

scrittura tutte le cose ed effetti naturali, e gl'intona nell'orecchio de l'interna mente per le concepute specie di cose visibili ed invisibili”. Cfr. trad. I. Gómez de Liaño, op. cit., p. 98.

94 Cfr. G. Bruno, De imaginum compositione, cit., liber II, p. 237.

95 G. Bruno, Cabala del cavallo Pegaseo, en Dialoghi italiani. I. Dialoghi metafisici. II. Dialoghi morali, cit., pp. 872-873. Sobre el tema de la verdad, cfr. B. Levergeois, op. cit., pp. 317-318. Para Bruno (op. cit., p. 837), cábala, teología y filosofía se hallan íntimamente relacionadas: "una cábala de filosofía teológica, una filosofía de teología cabalística, una teología de cábala filosófica,...”. [“(...) una cabala di teologica filosofia, una filosofia di teologia cabalistica, una teologia di cabala filosofica,...”]. Cfr. trad. M. Á. Granada, op. cit., p. 72. 
verdadero y causa de toda verdad es la "verdad superior o increada", a la que subordina la "verdad inferior o creada", la verdad por similitud. La verdad causal o real es el modelo de todo lo generado, la verdad natural es la totalidad generada, y la verdad nocional es la del conocimiento, iniciada en la cosa y ulterior a ella, y debe alcanzar tanto la verdad natural cuanto la real.

La ignorancia se halla en la sabiduría, ya que es el punto de partida y la guía para llegar a la verdad. Ignorancia y sabiduría se concilian con la unidad o verdad. Entre el universo y la divinidad hay una relación analógica que legitima la oposición entre la estulticia y la sabiduría. La unidad establece la analogía. Sabio es el asno ${ }^{96}$. En la Cabala, se profundiza y reflexiona sobre la simbología del asno que es el tema dominante de este diálogo ${ }^{97}$. Los aspectos simbólicos de la asinità se proyectan sobre el

96 Cfr. G. Bruno, op. cit., pp. 864, 871 y $873-874$. N. Ordine (op. cit., pp. 1-2, 8 y 33) sistematiza los significados teóricos de la asinità bruniana y analiza sus ambigüedades y valores opuestos, para presentar la coincidentia oppositorum de un modo paradójico por la fuerza de la humildad y la ignorancia docta. No separa el Bruno filósofo del Bruno artista ni la profundidad y singularidad de su pensamiento se alejan de su valor literario. El símbolo del asno se une a una intensa meditación y a un lenguaje bizarro y libre de prejuicios. La sabiduría y grandeza del hombre se vinculan al dolor y al esfuerzo del más humilde trabajo físico. El tema del asno y su uso simbólico en la complejidad de significados teóricos forman parte de la literatura del Cinquecento, desde Maquiavelo hasta Agrippa. La originalidad de Bruno se halla en el hecho de transformarlo en el motivo central de algunos aspectos esenciales de su reflexión, enriqueciéndolo con múltiples sentidos. El valor simbólico del asno se sitúa en un juego ambiguo de sus atributos positivos y negativos que revela algunos elementos constitutivos de una filosofía del conocimiento. Sobre la literatura del asno antes de Bruno, cfr. N. Ordine, op. cit., pp. 118-141.

97 El interés de Bruno por el tema del asno se manifiesta en escritos anteriores y posteriores a la Cabala (1585). En el Cantus Circaeus (cit., p. 198), París, 1582, en la explicación de la maga Circe sobre las ocultas correspondencias entre algunas cualidades de los hombres y de las bestias, el asno ocupa una posición central respecto de los otros animales. En el De umbris idearum (cit., p. 10), París, 1582, alude a la obra perdida el Arca di Noe, donde el asno es el protagonista principal, a propósito de la conveniencia de difundir escritos que son despreciados por la multitud y que sólo unos pocos entienden. Este es el caso del arte de la memoria que desaprobarán los ignorantes. Sin embargo, hay que transmitir las ideas para que estén al alcance de los que las comprenden y a pesar de los pedantes y asnos. En el Spaccio de la bestia trionfante (cit., pp. 597-598, 602-603 y 610), 1584, transforma la simbología de los mitos astronómicos para realizar la reforma moral del cielo. Los símbolos positivos sustituyen los negativos y los dioses decretan las variaciones, dejando vacío el espacio para que sea contemplado en cualquier parte de la tierra. En el aniversario de la victoria de los dioses contra los gigantes, Júpiter decide llevar a cabo la reforma celeste, la reforma moral del Zodíaco, reconociendo el valor y el peso determinante de los asnos. A propósito del fracaso de los falsos sabios de la Cabala y del Asino cillenico, en el De imaginum compositione (cit., liber II, pp. 237-239), Frankfurt, 1591, el locus Asinus Cyllenicus se halla en el espacio simbólico de Mercurio. Esta relación del asno con Mercurio pone de relieve la coincidentia oppositorum y acentúa la ambigüedad de esta pareja por sus cuali- 
hombre, ya que su imagen de mediador entre lo bestial y divino se corresponde con la divinidad y bestialidad del asno. La asinità es un espacio privilegiado para que los opuestos fluyan entre sí y transiten de lo serio a lo cómico, de lo bajo a lo alto, otorgándole el mismo valor a la entidad de los extremos. En determinadas circunstancias, la vista de un asno puede romper los límites entre la risa y el llanto y legitimar la disolución de las barreras entre lo serio y lo cómico ${ }^{98}$, que se hallan en el mismo plano de dignidad para captar la variedad que domina el universo ${ }^{99}$.

Para Bruno ${ }^{100}$, la ignorancia pura posee un carácter digno y excelso, porque es humilde, espontánea, mayestática y docta. La actitud noble del asno posibilita su conocimiento de la unidad infinita. El asno es humilde, puesto que reconoce su ignorancia respecto de todo posible saber. $\mathrm{La}$ brutalidad, aberración y demencia del asno son actos heroicos y divinos, ineludibles para ser sabio y aprehender lo oculto. El asno transciende las verdades de la ciencia, cuyo objeto de estudio son las disposiciones accidentales de la materia, soslayando sus formas substanciales. La ciencia puede ser responsable de la ruina cognoscitiva del hombre, de suerte que la negación del conocimiento científico es necesaria para alcanzar la más alta contemplación, la unidad, e identificarse con ella ${ }^{101}$. La única certeza cognoscitiva es la ignorancia, que se comunica con la absoluta sabiduría y coincide con el sumo saber.

(...) bajo la eminencia de la verdad no tenemos nada más eminente que la ignorancia y asinitade, porque ésta es el medio por el que la sabiduría se une y se domestica con ella; no hay otra virtud que sea capaz de tener la estancia unida con ella, pared con pared. Puesto que el entendimiento humano tiene cualquier acceso a la verdad, el cual si no es por la ciencia y el conocimiento, es preciso necesariamente que sea por la ignorancia y asinità ${ }^{102}$.

dades positivas y negativas. Mercurio describe los atributos del asno y éste los de Mercurio, manifestando que tutto in tutti.

98 Cfr. G. Bruno, Spaccio de la bestia trionfante, cit., p. 555.

99 Cfr. G. Bruno, op. cit., pp. 673-674.

100 G. Bruno, Cabala del cavallo Pegaseo, cit., pp. 838, 842 y 846.

101 Cfr. G. Bruno, op. cit., pp. 857 y 879-880; L. Spruit, Il problema della conoscenza in Giordano Bruno, Napoli, 1988, pp. 197-198.

102 G. Bruno, op. cit., p. 901: “(...) sotto l'eminenza de la verità non abbiam noi cosa piú eminente che l'ignoranza ed asinitade: perciò che questa è il mezzo per cui la sofia si congionge e si domestica con essa; e non è altra virtude che sia capace ad aver la stanza gionta muro a muro con quella. Atteso che l'umano intelletto ha qualch'accesso a la verità; il quale accesso se non è per la scienza e cognizione, necessariamente bisogna che sia per l'ignoranza ed asinità'. Cfr. trad. M. A. Granada, op. cit., p. 135. 
Se ejerce la ciencia o la ignorancia, ya que no existe un estado intermedio entre las dos. La sabiduría es este ejercicio de la ignorancia. El asno paradigmático se manifiesta en el núcleo de la unidad natural como principio generativo, pleno y formativo de cualquier especie asinina posible. Es el asno que examina las causas ocultas de las cosas, que averigua, más allá de la razón y de la ciencia, los misterios de la naturaleza, y evalúa las vicisitudes de la unidad cósmica. Es el asno que recorre el mundo material y sensitivo entendido como imagen del mundo inmaterial e inteligible ${ }^{103}$.

Para Bruno ${ }^{104}$, la ignorancia reviste distintos modos. El asno representa la ignorancia cuando se hace hincapié en la presunción de los ignorantes del derecho a enseñar sin saber nada. El triunfo de la asinità oscila entre lo positivo y lo negativo. La ignorancia positiva simple es la negación no sólo del saber sino también de la presunción del saber. La ignorancia positiva por excelencia es la que ni afirma ni cree saber, es la docta demencia, la más próxima a la divinidad y es despreciada por la mayoría de los hombres. El asno positivo puede acceder a la verdad por la luz racional, que niega toda iluminación sensible e intelectual, y por la luz de la fe, cuya iluminación procede de la luz inefable. Ésta es la guía hacia la sabiduría absoluta y evita todo posible error. El grado sumo del asno es llegar a la filosofía que está por encima de toda filosofía académica y escéptica, que se halla más allá de toda afirmación y negación, de toda sabiduría e ignorancia ${ }^{105}$. Los asnos positivos son el vehículo de la divinidad, así como la literatura lo es del pensamiento. La ignorancia negativa cree saber cada vez más pero nada sabe, puesto que su aparente sabiduría procede de las interpretaciones tradicionales de la verdad. Es el ignorante que no aspira a ningún tipo de afirmación (misticismo), que permanece en la duda (escepticismo) ${ }^{106}$ y que pretende conocer todo tipo de principios sin recurrir a la comprobación (cristianismo). Tanto el cristianismo como el escepticismo antiguo y moderno han renunciado a la investigación y comprensión de la verdad, protagonizando la decadencia y vejez de todos los órdenes del mundo ${ }^{107}$. La ignorancia cristiana, vincu-

103 Cfr. G. Bruno, op. cit., pp. 848, 852 y 854.

104 G. Bruno, op. cit., pp. 874-876. Asinità, pazzia, ignoranza son, a menudo, sinónimos.

105 Cfr. G. Bruno, op. cit., p. 906.

106 Cfr. G. Bruno, op. cit., pp. 902-903. La polémica de Bruno con el escepticismo antiguo es más morfológica que histórico-cronológica. Las relaciones de Bruno con el escepticismo (M. Ciliberto, Umbra profunda. Studi su Giordano Bruno, cit., pp. 195-197) no siempre fueron negativas, ya que en sus diálogos cosmológicos utilizó los trópicos escépticos.

107 Cfr. G. Bruno, op. cit., pp. 901 ss. 
lada a la escéptica, se manifiesta en las obras, costumbres y ciencias de la época. La parodia de los textos sagrados manifiesta las formas de la ignorancia cristiana. El dominio del escepticismo y del cristianismo en el conocimiento, en la religión y en la sociedad ha destruido el proceso del saber y coincide con la decadencia de los aspectos orgánicos del viejo mundo.

Ignorancia negativa es la de los escépticos y aristotélicos, los falsos filósofos y los pedantes que discuten estupideces y contaminan cualquier argumento con necedades ${ }^{108}$. Lo mismo puede decirse de los lectores que buscan el sentido de sus estúpidas palabras. En la Cabala ${ }^{109}$, presenta la disolución del lenguaje de la tradición, y parodia sus modos lingüísticos, alegorías, símbolos y metáforas. Los pedantes aspiran al inmovilismo temporal porque sólo son capaces de moverse en el complicado mundo de las reglas. Gramáticos y pedantes vegetan en el reino del ocio y se oponen a los que, con esfuerzo intelectual, investigan la manera de penetrar en el sentido de las cosas. Escépticos (nada sabemos) y aristotélicos (todo sabemos) son dos escuelas filosóficas con una actitud rígida y con una relación negativa con el saber. No aportan información porque domina la tautología sin constatación. La negación del sentido de los escépticos y la totalidad de los posibles sentidos de los aristotélicos indican una teoría del conocimiento común basada en la ideología de la quietud, en actitudes teóricas privadas de movilidad cultural. Se trata de un conocimiento fundamentado en un universo inmóvil, cerrado y alejado de las vicisitudes de la investigación del saber. Es una ignorancia que desprecia la filosofía de la naturaleza porque se cree depositaria de verdades universales. Frente a la complejidad del conocimiento, la ignorancia escéptica y aristotélica niega su existencia y propone el inmovilismo y estancamiento del saber, considerado tautológico y alejado de la aventura infinita del conocimiento. Esta ignorancia es ajena a una concepción fluida de la verdad, diseminada en pequeños fragmentos y en sintonía con un universo inestable y móvil, en el que las cosas sólo se ven en parte y no en su totalidad.

108 Cfr. G. Bruno, Spaccio de la bestia trionfante, cit., pp. 741-744. En la Cabala del cavallo Pegaseo (cit., p. 882, nota 1), Onorio abandona la región celeste en la que vivía como asno Pegaseo y se reencarna en el Estagirita en la tierra. Cfr. Séneca,

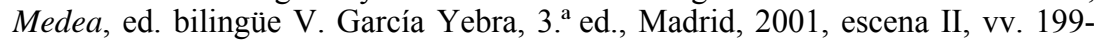
-200 , p. 61: "Qui statuit aliquid, parte inaudita altera, aequum liceo statuerit, haud aequus fuit" (Quien dictó la sentencia sin oir a una parte, aun siendo justo el fallo, cometió una injusticia). Estos versos de Séneca suelen ser citados por Bruno (por ejemplo, Artificium perorandi traditum a Iordano Bruno, cit., p. 61). De hecho, para Bruno (De immenso et innumerabilibus, cit., liber IV, pp. 55-56), gramáticos latinos, griegos, hebreos y caldeos definen las controversias filosóficas, juzgan y condenan sin la presencia y defensa legítima de todas las partes, ya que consideran que sólo ellos poseen los derechos y la luz de la estimación y comprensión divina.

109 G. Bruno, Cabala del cavallo Pegaseo, cit., pp. 902-905. 
La ignorancia negativa se asienta en un principio ininteligible para fundamentar un cuerpo teórico infalible que, a lo largo de la historia, ha prohibido la verdad natural (unidad cósmica) y la verdad divina (unidad absoluta) por el ejercicio de sus propias creencias y facultades ${ }^{110}$. "De esta forma nuestros divinos asnos, privados del propio sentimiento y afecto, vienen a entender no de otro modo como se les sopla al oído por las revelaciones de los dioses o de sus vicarios; y, en consecuencia, no se gobiernan según otra ley que la de aquellos mismos"111.

En definitiva, la asinità negativa conlleva la arrogancia y la ignorancia que impiden el conocimiento y la transformación civil. Es una ignorancia que niega la civilización y la vida terrena para afirmar una vida ultraterrena. La bestialidad del hombre se manifiesta en la arrogancia, la presunción, el inmovilismo del asno que vegeta en la eternidad, prisionero de sí mismo. La satisfacción es la condición de los asnos negativos ${ }^{112}$, que consideran el saber como creencia común frente a la naturaleza, la razón y los sentidos. Se encierran en sí mismos, se contentan con poco y creen hallarse en la totalidad. Esta negativa bestialidad es unidimensional y desde su interior es imposible elevarse hacia la divinidad. La asinità positiva implica humildad, esfuerzo y empeño en el progreso de la civilización y del saber. En este espacio positivo y negativo se configura la rueda de la metamorfosis ${ }^{113}$. Los asnos positivos viven en la luz de la sabiduría, pero son obstaculizados por los asnos negativos que vegetan en las tinieblas de la ignorancia, buscando lo fácil y vulgar porque carecen del impulso heroico para abandonar su existencia ociosa. Hay que alejarse de estos hombres y, si es necesario, ocultar el trabajo del esfuerzo para crear niveles ulteriores de selección ${ }^{114}$. La dignidad del hombre depende de los modos de comportamiento y de la intensidad de la laboriosidad. Sólo la asinità positiva podrá rescatar al hombre de su condición inmóvil y unidimensional para llevar a cabo su proceso de divinización por la

110 Cfr. G. Bruno, op. cit., pp. 876-878. Sobre la ignorancia positiva y negativa, cfr. A. Guzzo, op. cit., pp. 56-58; B. Levergeois, op. cit., pp. 318-319 y 321-325. Respecto de la ignorancia negativa, véase M. Ciliberto, La ruota del tempo, interpretazione di Giordano Bruno, Roma, 1986, p. 199. Aristóteles y el aristotelismo medieval representan la ignorancia filosófica, el judeo-cristianismo y su interpretación lutero-calvinista y erasmista simbolizan la ignorancia teológica.

111 G. Bruno, op. cit., p. 878: "Cossí li nostri divi asini, privi del proprio sentimento ed affetto, vegnono ad intendere non altrimente che come gli vien soffiato a l'orecchie dalle revelazioni o de gli dei o de' vicarii loro; e per consequenza a governarsi non secondo altra legge che di que' medesimi”. Cfr. trad. M. Á. Granada, op. cit., p. 113.

112 Cfr. G. Bruno, De gli eroici furori, cit., p. 975.

113 Cfr. G. Bruno, op. cit., p. 1003.

114 Cfr. G. Bruno, Spaccio de la bestia trionfante, cit., p. 716. 
aventura del conocimiento. La humildad, tolerancia y esfuerzo son necesarios para abandonar la naturaleza ferina y vivir de acuerdo con la humana. El universo de la asinità positiva es abierto y móvil, caracterizado por la vicisitud, mutación y metamorfosis. La humildad del asno, consciente de su propia asinità frente al saber universal, le permitirá investigar la laboriosa verdad que siempre se escapa. Sólo los asnos positivos, y por el uso de la razón, pueden emprender la aventura del conocimiento y alcanzar la divinidad ${ }^{115}$, porque son capaces de soportar las dificultades que impone la verdad. Para evitar las injurias de los asnos negativos, los asnos positivos deben ocultarse, superando diferentes pruebas con humildad, esfuerzo, perseverancia, movilidad y tolerancia, que son vías para llegar al conocimiento de las cosas naturales y de la complejidad del universo. Las cualidades del asno positivo, del asino anagogico ${ }^{116}$, son fundamentales para la exaltación de su actividad individual y para conquistar el saber y la inmortalidad, frente al infructuoso inmovilismo de los asnos negativos que nada o todo saben o que niegan la ciencia en nombre del saber divino.

La vida nos iguala a todos, aunque el acto y las formas vitales sean diferentes en cada cosa. El hombre es capaz de ser dio de la terra por su entendimiento y sus manos ${ }^{117}$. La mano simboliza la conformación corpórea del hombre. El hombre no puede huir de su condición animal y de su relación con otros seres vivientes que, junto con la acción de sus manos y entendimiento, le aproximan a la divinidad aunque no pueda llegar a su naturaleza absoluta. En la Cabala, las manos son el principal instrumento del hombre, ya que el entendimiento también lo poseen las bestias, y no es el símbolo de la superioridad del hombre sobre otros animales. Desde el punto de vista ontológico, la materia corpórea no se distingue de la incorpórea, y los sentidos y el entendimiento realizan un despliegue homogéneo por la escala universal del ser, de suerte que sólo la mano es el origen y lo específico de la civilización humana en el ritmo universal de la vicisitud de todos los destinos ${ }^{118}$. El don de la mano establece la superioridad del hombre respecto de los otros vivientes porque todos los seres poseen la misma alma. La vida depende de la estructura corpórea propia de cada ser y el modo de vida está sometido a la relación peculiar de la forma con la materia. Los hombres se distinguen entre sí por las cualidades naturales, y las divergencias entre los seres vivos se constituyen por

115 Cfr. G. Bruno, De gli eroici furori, cit., pp. 986-987 y 1120-1122.

116 Cfr. G. Bruno, Candelaio, cit., p. 36. La anagogía es el sentido místico y divino de la Sagrada Escritura, dirigido a la concepción de la bienaventuranza eterna, de suerte que el alma se aliena y eleva en la contemplación de lo divino.

117 Cfr. G. Bruno, Spaccio de la bestia trionfante, cit., p. 732.

118 Cfr. G. Bruno, Cabala del cavallo Pegaseo, cit., pp. 883-890. 
su particular acción instrumental. En este sentido, la mano es "el órgano de los órganos"119 que otorga la excelencia y superioridad del hombre respecto de las otras especies. Toda acción se realiza por las manos. El don de la mano ha posibilitado el paso de la naturaleza a la cultura y a la construcción de la civilización. La dominación del hombre sobre las otras especies se debe a su actitud natural y a la utilización de su corporeidad que transciende el instinto de supervivencia de los otros seres vivos y quebranta el ciclo natural y su equilibrio porque introduce la dimensión cultural en la naturaleza. La metamorfosis cultural del hombre se realiza para conservar su condición natural ${ }^{120}$. La mano es la causa de la valorización de los sentidos, de la fecundidad de la acción, de la revelación espiritual del hombre y de la ejecución de los dictados de la mente ${ }^{121}$. En la palma de la mano se revela la ley y el curso de la vida. La interpretación de los caracteres inscritos en las manos permite descifrar el destino de la vida. El alcance de la vida se conoce por las constelaciones celestes y por los signos de la mano. Se hace hincapié en la huella universal de los espacios vitales y en una ley y orden precisos que rigen la continuidad y vicisitud infinita. La ley es hija de la sabiduría que es la única posibilidad para comprender las vicisitudes sociales, pero el tiempo está más allá de cualquier valor, puesto que su acción igualitaria nada tiene que ver con el bien y el mal. La armonía del entendimiento y de la mano del sabio es la que permite la elección entre la virtud y el vicio. El descubrimiento de teorías filosóficas y científicas y la construcción de ciudades manifiestan la grandeza del hombre, pero su primacía ontológica sobre otros animales sólo se demuestra y confirma por la mano, que es un principio constitutivo y distintivo, una exclusiva y específica estructura corpórea del ser humano. La mano debe sustituir a la oreja ${ }^{122}$. El nexo único de voluntad y

119 G. Bruno, op. cit., p. 887.

120 Cfr. C. Monti, op. cit., p. 212. Esta concepción finalista de los órganos del cuerpo se opone a la aristotélica (De anima, ed. T. Calvo Martínez, Madrid, 1999, III, 8, 431b-432a, pp. 241-242) y se aproxima a la de Lucrecio (De rerum natura, ed. bilingüe E. Valentí y J. L. Ciruelo, Barcelona, 1985, LIV, vv. 820 ss., pp. 377-379).

121 Cfr. G. Bruno, De monade, numero et figura, cit., pp. 405-406. El hombre puede defenderse de sus enemigos ocultos por la imposición de las manos. El mago utiliza la fuerza de la naturaleza oculta del quinario y produce artificios maléficos en estatuas traspasadas por cinco heridas.

122 Los enormes genitales y la potencia de oír se consideran dos grandes cualidades del asno. Las grandes orejas del asno le permiten escuchar a gran distancia y es un atributo que subraya la perfección de la divinidad o de seres superiores. Esta capacidad es física y espiritual, ya que el verdadero conocimiento se halla unido al saber escuchar. Sobre las cualidades físicas del asno, cfr. G. Bruno, Cabala del cavallo Pegaseo, cit., p. 913. Acerca del conocimiento humano y el animal de la Cabala en relación con algunos versos del Zodiacus vitae, cfr. A. Ingegno, Cosmologia e filosofia nel pensiero di Giordano Bruno, Firenze, 1978, pp. 223-235. 
entendimiento podrá combatir la actitud ociosa, en la que el hombre es un mero oyente pasivo de las voces pedantes que le ordenan lo que tiene que hacer.

Tanto en el Spaccio cuanto en la Cabala, los principios esenciales para la construcción de la civilización son el esfuerzo, el mérito y la virtud, abandonando la actitud ociosa del paraíso terrestre, en el que se precipitaba su mundo. El ocio celebra la edad de oro ${ }^{123}$, el regreso a los orígenes de la humanidad, a su inocencia e instinto primario, ajeno al vicio y la virtud. La vida humana no se constituye en la brutalidad sino en la sociedad y la historia, cuyo progreso depende del ejercicio de las capacidades del hombre, que debe enfrentarse a las dificultades y necesidades de su época para preparar la llegada de un nuevo tiempo y cambio cósmico. En ambos diálogos ${ }^{124}$, la disolución de la civilización es evidente en todos los ámbitos del hombre. Bruno huye de la indiferencia entre vicio y virtud y busca un principio de moralidad que no disuelva pero distinga la humanidad de la bestialidad en el complejo proceso de la inagotable construcción de las civilizaciones. La maldad y la injusticia forman parte del origen de la virtud, por lo que ésta debe salir de la bestialidad por el esfuerzo, la diligencia y la solicitud, con el fin de separar el bien del mal y elegir la justicia. La virtud procede de una decisión consciente entre diversas posibilidades y no del puro instinto animal propio de la asinità. No hay virtud ni vicio sin elección, no hay moderación sin deseo ni pa-

123 Sobre la edad de oro, cfr. el III diálogo (pp. 725-829) del Spaccio de la bestia trionfante.

124 Bruno estuvo en París entre 1581 y 1583, llega a Londres en los primeros meses de 1583 y viaja a Oxford en junio de 1583 . Entre 1583 y 1585, Oxford y Londres se hallan en una intensa lucha política y religiosa. El Spaccio y la Cabala (1584 y 1585) se publican en la fase más áspera del enfrentamiento entre anglicanos y puritanos, cuyo uso ilegítimo de los principios civiles y políticos para atacar a la Iglesia y al Estado inglés podría desembocar en la disolución de ambos si no se producía una adecuada reacción. En la Epístola del Sigillus sigillorum (cit., pp. 76-78), publicada en Londres en 1583 y dirigida a los doctores de Oxford, utiliza un lenguaje y un método muy parecidos a los de la Cabala. Su enfrentamiento religioso con los doctores de Oxford -de diversas tradiciones culturales- se establece sobre un fondo filosófico y científico respecto de cuestiones bíblicas y teológicas, insistiendo en la diferencia entre filosofía y teología. En esta carta, el uso de textos bíblicos es sarcástico, y distingue con claridad entre anglicanos (más dispuestos a apoyarlo por las inclinaciones políticas de la reina Isabel) y puritanos o el extremismo protestante, contra los que la polémica es más radical. Por razones teológicas y religiosas, los puritanos refutaron la cultura italiana del Renacimiento, de ahí que Bruno defendiera la cultura universal del entendimiento que no diferenciaba entre italiano e inglés. (En La Cena atacará la cultura inglesa y reivindicará la italiana, sintiéndose orgulloso de pertenecer a ella). Sobre las relaciones del Spaccio y de la Cabala con la lucha religiosa, teológica y política en la Inglaterra de la mitad de los años ochenta, cfr. M. Ciliberto, Umbra profunda. Studi su Giordano Bruno, cit., pp. 229-270. 
sión. La virtud se encuentra en el trabajo, en la acción del entendimiento y de la mano. Si se sustituye la mano por la oreja, la sabiduría por la ignorancia, la curiosidad por la fe, y el esfuerzo por el ocio y la pedantería, se invertirán los significados de las palabras y todos los órdenes de la naturaleza. El comportamiento de acuerdo con lo que oyen las orejas transformará al hombre en asno y lo alejará de la virtud y de la acción de la mano. La crítica al ocio y pedantería de la vejez del mundo pretende restaurarlo y rejuvenecerlo por el esfuerzo y el trabajo. La gracia y la fortuna deben ser sustituidas por el mérito individual.

\section{El De gli eroici furori}

En 1585 publica los Eroici furori, el último de sus diálogos italianos, cuya ética de la templanza de los afectos se halla bajo la aniquilación del ser y la disipación de lo finito en lo finito. En De gli eroici furori, el alcance destructivo y la función devastadora de la pedantería han provocado la crisis de Europa. En esta investigación gnoseológica concurren aspectos esenciales de su ontología y ética, y los motivos de carácter histórico declinan de la situación del mundo en el destino de cada alma individual. En este diálogo procura suavizar la tensión con los círculos intelectuales, políticos y religiosos de la corte inglesa. La reforma interior del furioso conlleva una transformación política y social que permita, después del ciclo tenebroso hebraico-cristiano, la renovación del mundo a la luz de la antigua sabiduría, en la que el hombre y Dios hablaban el mismo lenguaje. El héroe es la autoafirmación del hombre. La existencia de una realidad transcendente no menoscaba el esfuerzo y la acción independiente de las fuerzas cognoscitivas del hombre, que debe concebir la divinidad como artífice y causa activa más que como simple receptáculo o instrumento. Los creyentes se limitan a acoger en sí lo divino, pero el héroe siente el impulso racional de elevarse hacia lo absoluto ${ }^{125}$. La divinidad se halla en el creyente, que la obedece, adora y admira. Los héroes son divinos, y su dignidad, potencia y eficacia posibilitan que lo divino se revele en la grandeza de la humanidad. La excelencia de la humanidad y su ideal de autonomía se confunde con la divinidad. El sentimiento del héroe supera la distinción dogmática entre naturaleza y espíritu y se dirige a la totalidad de la existencia para penetrarla en sí por la eliminación de los límites particulares. No se trata de amar el origen transcendente del ser sino cualquier fuerza natural, cuya unión con lo humano y lo divino es

125 Cfr. G. Bruno, De gli eroici furori, cit., p. 987. Sobre el héroe y lo absoluto, véase M. Bartolomé, "Lo absoluto y el amor en la filosofía de Bruno", Paideia, Actas del II Congreso de la Sociedad Académica de Filosofía, en CD-Rom, Santiago de Compostela, 10-12 de Febrero de 2005, pp. 1-37. 
vital y necesaria. No se puede amar lo que no se conoce, ya que el verdadero amor conlleva la condición necesaria del conocimiento. Todo lo que se ama se concibe bajo la idea de bien, que es el verdadero impulso de la voluntad. La imagen más perfecta de lo divino es el furor heroico, que tiende a ir más allá de sí mismo para encontrar la proporción más cercana a lo absoluto. El destino divino del hombre es su impulso hacia lo infinito, de suerte que la visión de la verdad nunca es saciada por la mirada intelectual, al igual que un objeto visible no limita ni colma el ojo sensible del hombre.

El vínculo del amor sella cualquier conexión con el mundo y comunica la dimensión natural con la divina. Por el amor, el furioso se encontrará a sí mismo en el objeto del amor y en el de la inteligencia, que se manifestarán como amante e inteligente, y se dirigirá al grado más alto en que amante e inteligente infinito coincidirán con su objeto de amor e inteligencia. El conocimiento de lo ajeno se convierte en algo propio. La contracción entendida como "sello divino" 126 hace posible la metamorfosis y disolución de los contrarios, ya que no hay contracción en la coincidencia final y suprema, hacia la que tiende el conocimiento y a la que se predispone en su decisivo momento pasivo, junto con la concesión de la gracia divina, la experiencia heroica del amor.

En el pensamiento filosófico de Bruno, los conceptos de la Antigüedad se vinculan al mundo de los mitos, cuya distinción entre hombre y universo es determinante para la explicación afectiva y sentimental del hombre. En los Furori, la renovación del hombre y su experiencia extraordinaria por el esfuerzo y estudio es explicada por el mito de Acteón y Diana $^{127}$. Acteón es el cazador devorado por los perros después de haber contemplado la desnudez de Diana. En el Candelaio ${ }^{128}$, representa el turbio amor de Bonifacio, en los Furori simboliza la perfección del amor heroico. En ambas obras, los bajos impulsos del alma inferior provocan el desgarro producido por los perros. En los Furori, el verdadero Acteón se transforma en ciervo selvático para alcanzar una comunicación directa con Dios. Desde el punto de vista metafísico, el vínculo entre contemplación y acción se legitima en una concentración destinada a otorgar un poder superior por la conversión del cazador en ser cazado y por la coincidencia de la acción humana con la divina. La finalidad de la caza solitaria del furioso es una comida espiritual que está más allá de la comida humana e incluso de los frutos procedentes del restablecimiento de las reglas civiles y religiosas y de la purificación del mundo humano y de sus

126 G. Bruno, Spaccio de la bestia trionfante, cit., p. 797.

127 Cfr. G. Bruno, De gli eroici furori, cit., pp. 946, 995, 1008-1009, 1022-1025, $1088-1089$ y $1123-1125$.

128 G. Bruno, Candelaio, cit., p. 27. 
valores del Spaccio. La reina Isabel es Diana en la historia, cuya misión es abrir la vista mental y generar una nueva época que soslaye el agotamiento intelectual a la luz de una filosofía de la naturaleza, de la ciencia y de la literatura. El ciervo doméstico es la metamorfosis propia del falso Acteón, que es el sacerdote cristiano, el cazador de una Diana falsa, Cristo, que se apropia de la función de víctima y sacerdote, convirtiéndose en el único mediador entre hombre y Dios. El sacrificio de Cristo se revela como la única posibilidad de comunicación entre lo humano y lo divino, en cuanto que, alimentándose con su cuerpo, el hombre cree alcanzar la divinidad. Esta metamorfosis de Acteón en ciervo doméstico se realiza por una ordenación sacerdotal y por una Diana identificada con la Iglesia, de tal modo que sacerdote y bestia son lo mismo, y no hay diferencia entre comerse el cuerpo de Cristo y la víctima del sacrificio. En este mundo de locura cristiana, Cristo y la bestia no se distinguen. El género heroico y aristocrático de la caza se presenta como algo insensato y sin valor, ligado a la ineptitud de las acciones gloriosas de la guerra y a los rituales y engaños religiosos. En virtud de la estupidez humana, la apoteosis de la caza culmina en la transmutación de bestias cazadas y sacrificadas. En el Spaccio ${ }^{129}$, el contenido civil otorga dignidad a la caza real, que se opone a los actos irracionales de los sacerdotes porque proporciona los medios para combatir la vida pública, siendo la utilidad social el único valor de las creencias ${ }^{130}$.

En el seno de la crítica al ocio intelectual, Bruno condena la literatura petrarquista por su lenguaje repetitivo sin contenido edificante. El petrarquismo y su concepción antropológica de una sociedad que aspira al inmovilismo temporal y a la negación del futuro, vivía su última fase de disgregación en la época de Bruno ${ }^{131}$. A Bruno le interesa la provocación del contenido poético y se aleja de la poesía clásica y de la de Petrarca porque su destino es la parte externa del amor. La literatura tiene que ser un instrumento para cautivar las ideas, y los pedantes no pueden decidir su destino, ya que sólo son capaces de moverse en el complicado mundo de las reglas.

Bruno $^{132}$ distingue entre la actividad del crítico, que especifica los

129 G. Bruno, Spaccio de la bestia trionfante, cit., pp. 813-814.

130 Sobre este tema, cfr. E. Cassirer, op. cit., p. 159; A. Ingegno, La sommersa nave della religione. Studio sulla polemica anticristiana del Bruno, cit., pp. 137-141; Regia pazzia. Bruno lettore di Calvino, cit., pp. 12, 70-72, 76-77 y 84-86.

131 G. Bruno, De gli eroici furori, cit., pp. 928-929.

132 G. Bruno, op. cit., pp. 957-961. Bruno se halla entre la concepción autónoma de la poesía de la filosofía moderna y la de la primacía de la poesía sobre otros modos de comunicación y expresión, propia de Dante hasta mediados del Cinquecento. Bruno se encuentra entre el orden, la estabilidad y la eternidad de la poesía del Renacimiento, y la apertura, el movimiento, la pluralidad de lenguajes y acti- 
modos y formas poéticas, y la actividad del poeta que se concentra en la creación artística. La consideración aristotélica de la épica de Homero como norma absoluta y universal para hacer poesía no es admitida por Bruno, ya que es necesario abandonar una literatura constituida por estériles imitaciones. Para hacer literatura, hay que eliminar esta concepción absoluta y sus preceptos universales. Las reglas aristotélicas se establecieron por el modelo de los poemas de Homero, que son los únicos que ilustra. Aristóteles estableció reglas a posteriori sólo para la poesía épica y a priori para los imitadores de Homero; pero los aristotélicos las aplicaron a priori a toda la poesía. Estas reglas y las de los pedantes contemporáneos pretenden excluir toda la poesía que no comulgue con sus etiquetas y definiciones, con las metáforas conformadas por insensatas normas. En virtud de que el origen de la poesía de Homero no son las reglas, Bruno la considera modelo de la verdadera poesía. Las reglas pueden estimular pero no delimitar la esencia de la poesía. La crítica debe concretar innumerables reglas de los infinitos modos poéticos para establecer la lectura, interpretación y articulación del texto poético, pero no tiene que especificar el uso de unas reglas absolutas ni de un paradigma único como medida del valor artístico. Las formas y figuras literarias tradicionales se pueden utilizar pero con conciencia crítica. El gran juego del lenguaje es necesario para producir un cambio radical en los temas y lenguajes de la tradición. Bruno rompe con el principio renacentista de la correspondencia entre la poesía y determinados modelos, y reivindica la singularidad de cada texto poético y su vinculación a la experiencia y al ser del hombre en su infinita posibilidad. El horizonte de la poesía es el lector con el que se relaciona por el placer y el deleite, que es individual e irrepetible por la sensibilidad y el ingenio de cada poeta. El crítico, el lector, debe ser capaz de hallar la particularidad del artista entre los innumerables modos de delectación poética. La poesía manifiesta la infinita posibilidad del ser del hombre y mantiene una relación armónica con la crítica teórica, que expresa la singularidad única de cada texto poético. Hay tantos tipos de poetas cuanta diversidad de ingenio humano. Frente a la poesía mediocre que envidia la novedad y lo sublime, limitada por normas absurdas y censuras lingüísticas, Bruno defiende la poesía auténtica en su originalidad, que mezcla sin escrúpulos géneros, lenguajes, fórmulas sintácticas, y que está al servicio de la conquista filosófica en la que triunfa como alegoría.

En los Furori, el héroe se halla entre la sombra y la luz que ilumina

tudes formales del Barroco, en el que cada escritor integrará dicha multiplicidad en una infinita serie de composiciones. Sobre la concepción bruniana de la poesía, cfr. G. Bàrberi Squarotti, op. cit., pp. 15 y 90-92; P. Sabbatino, op. cit., pp. 9, $86-95,108$ y $111-114$. 
al ciprés ${ }^{133}$. Los personajes no pasean como los peripatéticos sino que dialogan sentados y expresan la acción dramática en el teatro de la vida, siendo los diálogos sólo un medio para el relato. La experiencia dramática del furioso consiste en su esfuerzo mental para llegar a lo absoluto. Este esfuerzo es representado por el entrelazamiento de poesía y prosa. La poesía expone la teoría del conocimiento y del amor. La prosa alienta y vivifica un sistema que parte y regresa al amor. Es una prosa que permite la comprensión y la interpretación del sentido literal de la historia natural del amor del hombre hacia el Dios inmanente. La verdad es el único sujeto conveniente de la poesía, en cuanto que ésta es literatura destinada a la filosofía, que la precede y genera, e interpreta y comenta la poesía heroica. Ésta prevalece sobre la poesía del amor porque su origen es la filosofía y su fin es mejorar la vida política y social del hombre. La poesía bruniana es una parábola de amor entre el Dios inmanente y el hombre. En lugar de dedicarse al amor ordinario, la poesía debe ocuparse del amor heroico de la mente que busca el Dios inmanente, el objeto fundamental de la filosofía de la naturaleza. La poesía y la prosa tienen que representar una nueva literatura y escritura, libre de cualquier tradición, con el fin de describir el itinerario del entendimiento hacia lo absoluto.

El furor heroico huye de la diversión ociosa y del engaño del lenguaje, cuyo canto poético se dedica a la descripción de un estado de ánimo melancólico y estúpido por una acumulación vertiginosa de palabras que, a su vez, expresa las múltiples bellezas de la mujer. El furor heroico de la verdad se opone a la celebración ridícula e insensata del sentimiento hacia la belleza de una mujer que se muestra dura y cruel hacia el amado.

133 Bruno combina temas platónicos con imágenes de las Sagradas Escrituras, sobre todo del Cantar de los cantares, que constituye el nexo entre el De umbris y los Furori. El Cantar de los cantares es el modelo de los Furori. El tema del amor de dos jóvenes en la distancia, búsqueda y encuentro o el vínculo del amor entre la Iglesia y Cristo -según el significado cristiano-, se plantea como una metáfora del amor entre el furioso y el Dios inmanente, que conlleva la plenitud y felicidad del hombre. En el Cantar de los cantares, las metáforas y los conceptos eróticos sobre la belleza de la mujer son alegóricos, por lo que sólo Salomón puede aclarar lo que ha querido decir. La interpretación alegórica sólo se puede aplicar más allá del significado literal, de suerte que sólo es objetiva cuando es confirmada por el autor. El lector de los Furori puede confiar en las declaraciones de su autor, cuya poesía de amor pretende comprender el significado profundo de la pasión por la búsqueda de la verdad del universo. El autor puede decir en persona sus intenciones, testimoniando que los Furori es un texto alegórico, pero no un sueño o una profecía enigmática que necesite, en un futuro, de la interpretación alegórica. La autoridad del autor presente supera las alegorías arbitrarias e insensatas que fundamentan la exégesis bíblica en general. El juego de la exégesis utiliza el texto con fines apologéticos y atribuye diferentes valores a las palabras que son enigmas, sueños y locuras de los profetas. Sobre este tema, cfr. G. Bàrberi Squarotti, op. cit., pp. 75-76; P. Sabbatino, op. cit., p. 95. 
Toda esta ornamentación banal esconde, por convenciones sociales, el instinto de provocación cotidiano, burgués y vulgar. El lenguaje debe dirigirse al furor que guía a la conquista de la verdad del universo, y tiene que evitar lo frívolo y fatuo y no limitarse al amor y al sexo que sólo forman parte de la vida común y de los impulsos de la naturaleza. Un lenguaje ocioso, indigno y mediocre revela la locura de amor por una mujer. La extenuación y superación de antiguos afectos es la condición necesaria para la consolidación de nuevos vínculos. Se trata de un ciclo natural, en el que las exhaustas pasiones dan paso al vínculo de los vínculos que es el amor. El significado profundo de la pasión se comprende por la búsqueda de la verdad del universo. El objeto de la dignidad del hombre es el furor, el esfuerzo y los sentimientos necesarios para alcanzar la verdad absoluta en su esplendor. El fin no es la verdad en sí sino la alienación del héroe para conquistar lo que ha sido definido y conceptuado por la filosofía: la verdad del universo.

Soria, 08 de junio de 2008 